\title{
Congenital cataract: the history, the nature and the practice
}

\section{Introduction}

In his 1933 Doyne Lecture A.B. Cridland cited Emmerson: 'An institution is the lengthened shadow of one man.' The Oxford Congress is such an institution, founded on 15 July 1909, ${ }^{1}$ with Robert Walter Doyne as the first Master; it holds a special place in the academic calendar of ophthalmologists around the world because of its academic excellence, the beautiful city in which the meeting is held, and the warmth and conviviality of the members. I was particularly pleased and proud to be asked to give the 75th Doyne Lecture in the 80th year of the lectureship because this is the first such lecture to be given by a British paediatric

ophthalmologist and it is given at a time when paediatric ophthalmology in general and in the British Isles in particular is flourishing clinically and academically. I chose congenital cataract as my subject not only because it has been a lifelong interest: it is still the major preventable cause of lifelong visual handicap, and there are a number of controversial areas which have not yet been resolved.

\section{History}

Although couching for cataract was practised in the Hellenistic period, ${ }^{2}$ its use in children was not ideal: an already tricky operation was turned into an exceptionally difficult one by the child's anatomy and the lack of an anaesthetic. Pott, ${ }^{3}$ the ophthalmologist to St Bartholomew's hospital, introduced the discission operation which was to remain in use for nearly 200 years. It consisted of making an incision of one or another shape and size in the anterior capsule, leaving the aqueous to absorb the lens material over a few weeks; however, a thick capsular membrane usually resulted, and glaucoma was frequent. Most practitioners of discission used an anterior approach but Saunders ${ }^{4}$ advocated a posterior approach, because the dispersion of the lens material into the vitreous was, he considered, more effective. Ziegler ${ }^{5}$ in 1921 described a technique of 'through and through' needling, using two bold V-shaped cuts: 'Boldness in incision is a virtue, timidity a vice'.
There could not have been enough sufficiently bold surgeons around as the technique never caught on, although Ziegler's knife can still be bought today.

Gibson, ${ }^{6}$ from Birmingham, used a technique in which the couching needle was used to rupture the anterior capsule and the eye was left to settle over a period of 2 or 3 weeks. Then an incision, made 'by a corneal knife of the largest size' was used to extract the cataract: 'as the knife is withdrawn, aqueous and some of the cataract evacuate spontaneously or helped by a curette'. Gibson's technique was to become known as linear extraction, and was used world-wide for nearly 150 years. Many authors used a combination of the techniques; linear extraction gave the best vision, but discission, being the simplest, was the safest.

Scheie and Ewing ${ }^{7}$ described the history of aspiration of the lens through a small incision. Rhazes, a Persian physician and philosopher, mentioned its use by Antillus, a contemporary of Galen, in the fourth century AD. Aspiration was practised in Japan in the fifteenth century, in Italy in 1829, and by Laugier in 1847, and modifications of the technique came into and just as easily went out of fashion, mostly because of technical difficulties. Teale's ${ }^{8}$ cannula was an ingenious device in which a fine cannula that was inserted into the lens via a small incision at the limbus had suction applied to it through a rubber tube running to the surgeon's mouth. Scheie ${ }^{9}$ described the technique of lens aspiration that was to be the basis of numerous subsequent methods; the use of the operating microscope in infant cataract surgery, ${ }^{10}$ new sutures and instruments took it to new levels.

Although there were some advocates of intracapsular cataract extraction in children, ${ }^{11,12}$ complications were too frequent.

As the Industrial Revolution brought about improvements in the quality and availability of surgical instruments, so surgeons became bolder in their techniques. Treacher Collins ${ }^{13}$ simply couched a persistent hypoplastic primary vitreous (PHPV) membrane; others, later attempted to remove them. Alexander ${ }^{14}$
D. Taylor

Department of Ophthalmology Great Ormond Street Hospital for Children London WC1N 3JH, UK

Tel: $+44(0) 1718298651$ Fax: $+44(0) 1718298647$ 
'seized the disc by the iris forceps and extracted it only a drop of vitreous escaped and the result has been entirely satisfactory'. Some of the applications of new technology were most imaginative: Nutt, ${ }^{15}$ for instance, preceded radiofrequency capsulorhexis by 35 years, even if his diathermy technique didn't catch on!

\section{Amblyopia in congenital cataract}

Juler, ${ }^{16}$ in 1921, noted that traumatic cataracts operated before 5 years of age did badly, whereas those operated after 5 years did relatively well. As ophthalmologists became aware of the ground-breaking work of the amblyopia researchers, so they realised how it affected their management of congenital cataract. ${ }^{17,18}$ There are a number of clinical observations that reinforce the importance of amblyopia on the visual outcome following cataract surgery:

1. Early treatment brings about better visual results. Once the importance of amblyopia became evident, good visual results were obtained by the early treatment of previously unrewarding cases of unilateral cataract. ${ }^{19}$

2. Early and continued optical correction is essential in infant surgery. It is likely that the poor results of cases operated in infancy in early studies ${ }^{20,21}$ were due to the lack of optical correction. Today, cases with early surgery but later optical correction have a worse prognosis than those with early optical correction. ${ }^{22}$

3. Occlusion of the phakic eye in unilateral cataract is as essential as early surgery and optical treatment. ${ }^{23}$

4. Poor compliance with optical treatment and occlusion reduces the quality of the visual results. ${ }^{24-27}$

5. In bilateral cataract, the first operated eye achieves the better vision ${ }^{28-30}$ in the absence of pre- and immediately post-operative occlusion, in cases with even only a few days between the operations on the two eyes.

6. Later deprivation does not give rise to additional visual defect. ${ }^{16,31}$

7. Brief early deprivation, before the critical period, does not affect vision. ${ }^{32,33}$

8. In asymmetrical, bilateral cataracts, the more severely affected eye develops the worse vision. ${ }^{18}$

\section{Early referral}

As the importance of amblyopia became established, ${ }^{17,32}$ so did the necessity for early referral. Many ophthalmologists went through a stage of treating congenital cataracts as a 'semi-emergency'. ${ }^{34}$ Although not strictly necessary on the grounds of treating amblyopia, the attitude led to earlier referral through publicity and the teaching of paediatricians about the need to detect cataracts in neonates. ${ }^{35-37}$ In most units specialising in congenital cataract the majority of referrals are now infants in the first weeks of life. ${ }^{38}$

\section{Epidemiology}

Population-based studies have suggested a prevalence of 1.2 per 10000 total births, ${ }^{39} 2.1$ per 10000 live births ${ }^{40}$ or 2.3 per 10000 total births. ${ }^{41}$ These figures are almost certainly low as the data are gathered at diagnosis, or from inpatients symptomatic in the first year of life, ${ }^{40}$ or from discharge abstracts of live or still-born babies, ${ }^{39}$ or from a malformation register. ${ }^{41}$

Screening of 2447 4-year-olds ${ }^{42}$ gave 7.7 cataracts per 10 000, and two birth cohort studies suggested a prevalence of $5.3^{43}$ and 4.4 per $10000 .^{44,45}$ Between $40 \%{ }^{43}$ and $55 \%{ }^{40}$ of these cases are unilateral. A current British nation-wide active surveillance study with high ascertainment by Dr Jugnoo Rahi at the Institutes of Child Health and Ophthalmology in London suggests that the cumulative incidence in the UK is between 2 and 3 per 10000 live births per year.

New registrations of patients with congenital cataract, aged 0-15 years, from the National Registers of Partial Sight and Blindness, England and Wales suggest that there may be a decrease in the percentage of registrations due to cataract. This decrease may be due to an improvement in management and to changes in attitudes towards registration.

\section{Natural history \\ Pathogenesis}

The mechanisms of cataractogenesis are not well understood. Insights have been gained from conditions such as galactosaemia where water is osmotically drawn into the lens by the accumulation of galactitol, causing the 'oil-droplet' refractive change in the central part of the lens. Further hydration leads to the swelling and rupture of lens fibres, and the formation of a cataract. ${ }^{46}$ Bilateral cataract is almost invariable in untreated 'classical' galactosaemia due to galactose-1-phosphate uridyl transferase deficiency; ${ }^{47}$ it occurs in the rare epimerase deficiency, ${ }^{48}$ but in galactokinase deficiency the lens is less certainly involved. Galactokinase-deficient persons may be prone to presenile or infantile cataracts ${ }^{47}$ but some studies have failed to confirm this. ${ }^{49,50}$

Marginal maternal deficiency of galactose enzymes may underlie some congenital cataract. ${ }^{47,51}$

Familial sorbitol dehydrogenase deficiency is also associated with cataracts, ${ }^{52}$ which probably have a similar largely osmotic mechanism. Accumulation of mannose-enriched oligosaccharides in the posterior parts of the lens is associated with capsular opacities in mannosidosis. ${ }^{53}$

Hypoglycaemia in infancy, of any cause, may give rise to cataracts, ${ }^{47,54-56}$ but the mechanism is not clear. The metabolic defect is usually profound; most affected infants have convulsions and many have permanent brain damage. ${ }^{57}$

Hypocalcaemia also causes infantile cataracts, ${ }^{58-60}$ usually of less functional significance than hypoglycaemic cataracts. Calcium plays an important 
role in cell signalling ${ }^{61}$ related to acetylcholine receptors which liberate calcium from intracellular stores in the lens.

The occurrence of cataracts in the Smith-Lemli-Opitz syndrome, ${ }^{62,63}$ in which there are low levels of plasma cholesterol and high 7-dehydrocholesterol, in cerebrotendinous xanthomatosis, which also has high levels of cholestanol in tissues including the lens, and in mevalonic aciduria, together with cataract production by inhibitors of cholesterol in the lenses of experimental animals, suggest an important role for cholesterol in the structure and maintenance of lens cell membrane structure. $^{64}$

Oxidative damage has been implicated in cataractogenesis: oxygen-derived free radicals are highly reactive compounds which can oxidise lipids and proteins can cause cell membrane damage and alterations to cell function ${ }^{65,66}$ this damage is accelerated by UV light, ionising radiation, hyperbaric oxygen ${ }^{67}$ and high concentrations of transitional metal ions. ${ }^{68}$ This damage is normally prevented by cellular antioxidants such as superoxide dismutase, glutathione peroxidase, ascorbate and vitamin E. Thirty-three per cent of young rats brought up on a diet containing low levels of both tryptophan and vitamin E develop cataracts. ${ }^{69}$ Patients with Down's syndrome have increased free radical activity, ${ }^{70}$ perhaps due to the trisomy giving high levels of CuZn-superoxide dismutase, the gene for which is carried on chromosome 21. Cataracts may be prevented by antioxidants. ${ }^{61}$

Transient cataracts occur in premature infants; ${ }^{71-74}$ in most cases the pathogenesis is obscure. Alden et al.'s cases $^{72}$ had mostly received kanamycin, and had been acidotic, suggesting a metabolic cause. In some, the cataracts have been clearly associated with treatment for retinopathy of prematurity; ${ }^{75,76} 93 \%$ were associated with laser treatment and $3 \%$ with cryotherapy. ${ }^{76}$

Ninety per cent of water-soluble lens proteins are crystallins. ${ }^{77}$ They are contained in the lens fibres, and have a spatial arrangement and order which is imporant for the clarity of the lens. Three major classes of crystallins $-\alpha, \beta$ and $\gamma$ - are distinguished on their chromatographic properties, the $\alpha$ being of the highest molecular weight, the $\gamma$ the lowest. They are very stable proteins, resisting denaturation by oxidation, UV radiation and racemisation. The $\gamma$-crystallins mostly occur in the lens nucleus, ${ }^{78}$ the site of the Coppock cataract in which a mutation of the $\gamma$-crystallin gene has been found. ${ }^{79}$ A cerulean cortical cataract is linked to the $\beta$-crystallin region on chromosome $22 \mathrm{q} ; \beta$-crystallins are mostly found in the lens cortex. ${ }^{78}$ The gene for the major intrinsic protein (MIP) of the human lens fibre cell membrane has been mapped to chromsome $12 \mathrm{q}^{80}$

\section{Genetic heterogeneity}

Genetic heterogeneity has been demonstrated in a number of families using a variety of gene markers. ${ }^{81-84}$ There is probably a close association between the morphology and the gene locus; ${ }^{85}$ hence a pulverulent cataract involving the cortex as well as the nucleus is not linked to the Duffy blood group ${ }^{86}$ as is the Coppock cataract $^{87}$ (Table 1).

\section{Morphology}

The morphology of cataract is important for several reasons: it can give a clue to the age of onset, to the visual prognosis, it may suggest heritability, and it may give a clue to the aetiology. Some morphological types have a better visual prognosis than others, with lamellar cataracts and posterior lenticonus doing well and dense central cataracts relatively poorly. ${ }^{103-105}$ Phenotypic heterogeneity (Fig. 1) is a prominent feature in many families, particularly with autosomal dominant congenital cataract; ${ }^{82,84,85,106,107}$ there are inter-ocular (Fig. 2), morphological and intrafamilial differences within a pedigree.

In congenital Morgagnian cataracts, named after Giovanni Morgagni who described them in 1762, the outer zones of the lens become liquefied whilst the nucleus remains intact. This allows the nucleus to fall by gravity in any direction, depending on the position of the head.

Table 1. Gene loci linked with cataract types

\begin{tabular}{llll}
\hline Cataract type & & Author and reference & Gene locus \\
\hline Volkman, nuclear & PD & Eiberg et al. $(1995)^{88}$ & $1 \mathrm{p} 36$ \\
Posterior polar & AD & Ionides et al. $(1997)^{85}$ & $1 \mathrm{p}$ \\
Zonular pulverulent & AD & Renwick and Lawler $(1963)^{87}$ & $1 \mathrm{q} 21-25$ \\
Coppock-like & AD & Lubsen et al. $(1987)^{89}$ & $2 \mathrm{q} 33-36$ (y-crystallin region) \\
Polymorphic & AD & Rogaev et al. $(1996)^{90}$ & $13 \mathrm{q}$ \\
Polymorphic & AD & McKay et al. $(1997)^{91}$ & $13 \mathrm{q}$ \\
Nuclear and lamellar & AD & Marner et al. $(1989)^{92}$ & $16 \mathrm{q}$ \\
Anterior polar & AD & Berry et al. $(1996)^{93}$ & $17 \mathrm{p}$ \\
Zonular, sutural & AD & Padma et al. $(1995)^{94}$ & $17 \mathrm{q} 11-12$ \\
Cerulean & AD & Armitage et al. $(1995)^{95}$ & $17 \mathrm{q} 24$ \\
Cerulean & AD & Kramer et al. $(1996)^{96}$ & $22 \mathrm{q}(\beta-c r y s t a l l i n$ region) \\
Nance-Horan syndrome & X-LR & Lewis et al. $(1990)^{97}$ & Xp22.2-22.3 \\
Nance-Horan syndrome & X-LR & Zhu et al. $(1990)^{98}$ & Xp22.2-22.3
\end{tabular}

$\mathrm{AD}$, autosomal dominant; $\mathrm{XL}-\mathrm{R}, \mathrm{X}$-linked recessive.

Chromosomal translocations $2 ; 14,{ }^{99} 2 ; 16,{ }^{100} 3 ; 4,^{101} 3 ; 18^{102}$ have suggested candidate sites. 


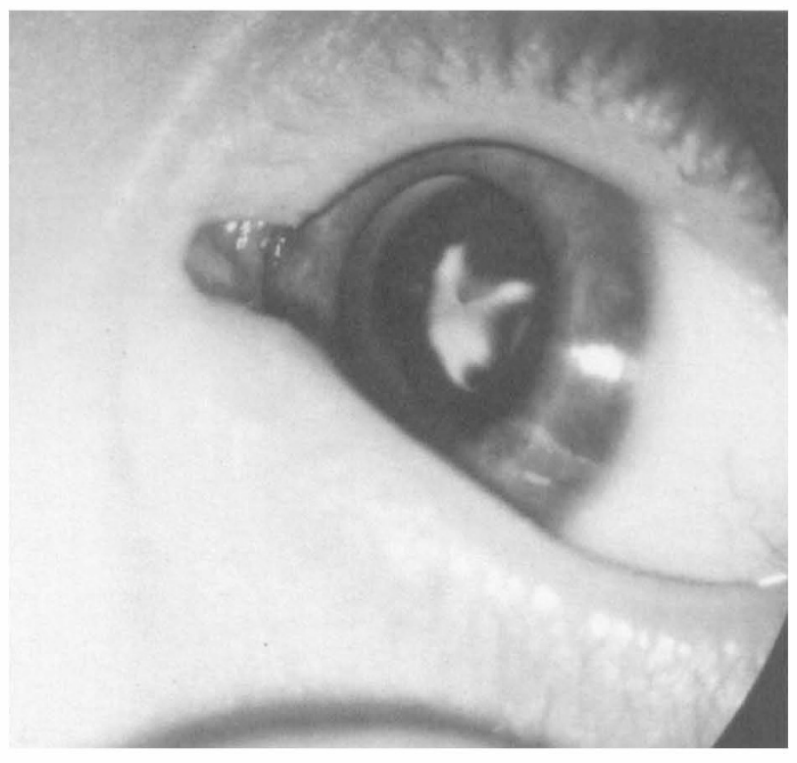

(a)

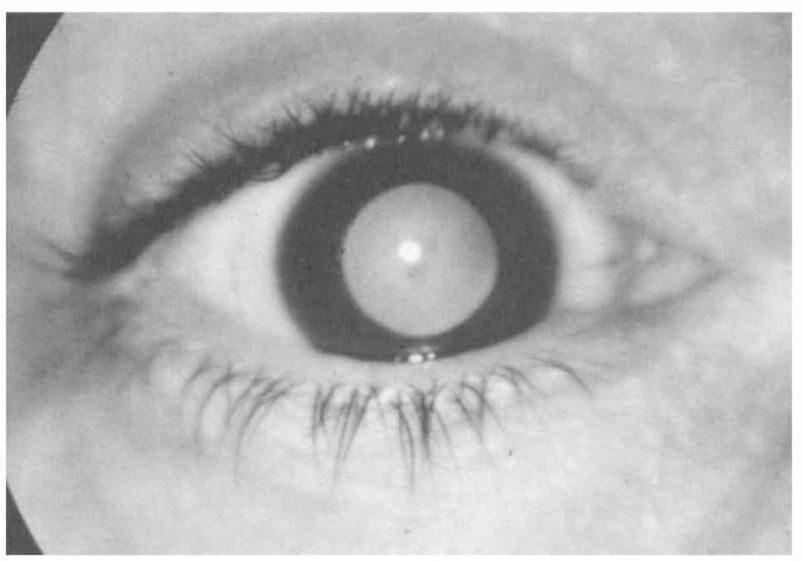

(b)

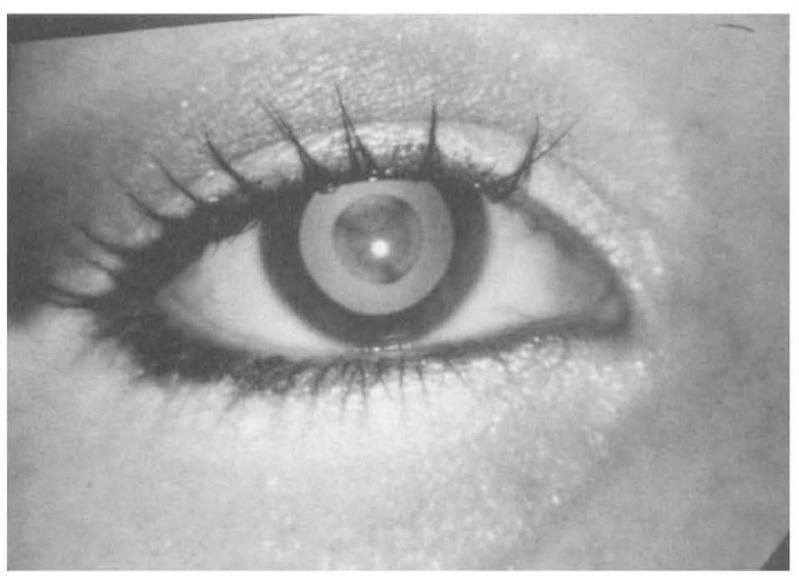

(c)

Fig. 1. Autosomal dominant congenital cataract presenting in infancy (a). Also shown are the patient's mother (b) and grandmother (c), who are asymptomatic.

Total cataracts involving the whole or nearly all of the lens occur in Down's syndrome, acute metabolic cataracts and congenital rubella (where 'shaggy' nuclear cataracts are more common), but may be seen in familial or sporadic cases.

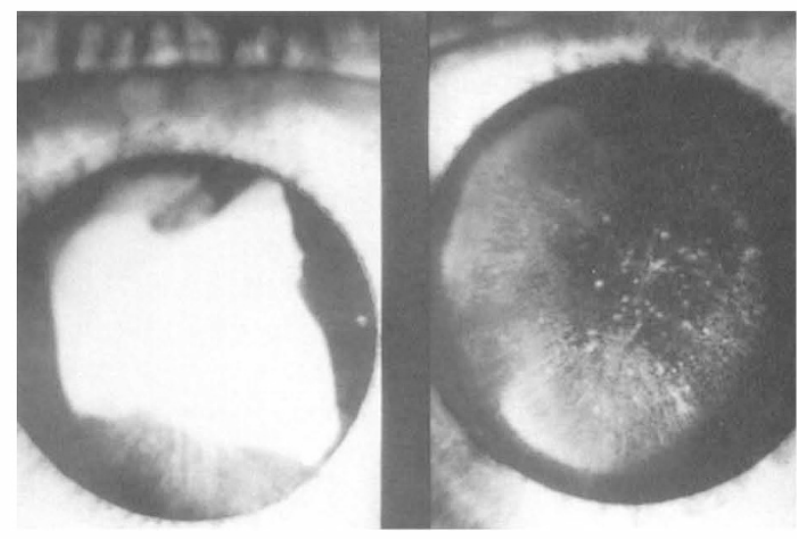

Fig. 2. Interocular phenotypic variability in a patient with pulverulent cataract.

Disc-like and membranous cataracts represent varying stages of reabsorption of the lens, leaving either a disc of lens material or a bag of milky or crystalline substance, or the anterior and posterior capsules fused together (membranous cataract). It is common in persistent hypoplastic primary vitreous (PHPV), ${ }^{108}$ and has been described in congenital rubella, ${ }^{109-111}$ in the Hallermann-Strieff syndrome, ${ }^{112,113}$ aniridia, ${ }^{114}$ Lowe's syndrome ${ }^{115,116}$ and in a patient with the Pierre Robin sequence, ${ }^{117}$ and it may occur after rupture of an anterior lenticonus. ${ }^{118}$ When the reabsorption occurs in a localised area, a hollow doughnut-shaped ${ }^{119,120}$ or a sector-shaped membranous ${ }^{121}$ cataract may result.

Dot-like anterior polar cataracts were described early in the twentieth century. ${ }^{13}$ These are tiny white dots on the anterior surface of the lens in the axial area that probably represent abnormalities of lens vesicle detachment. They vary in size from one case to another,

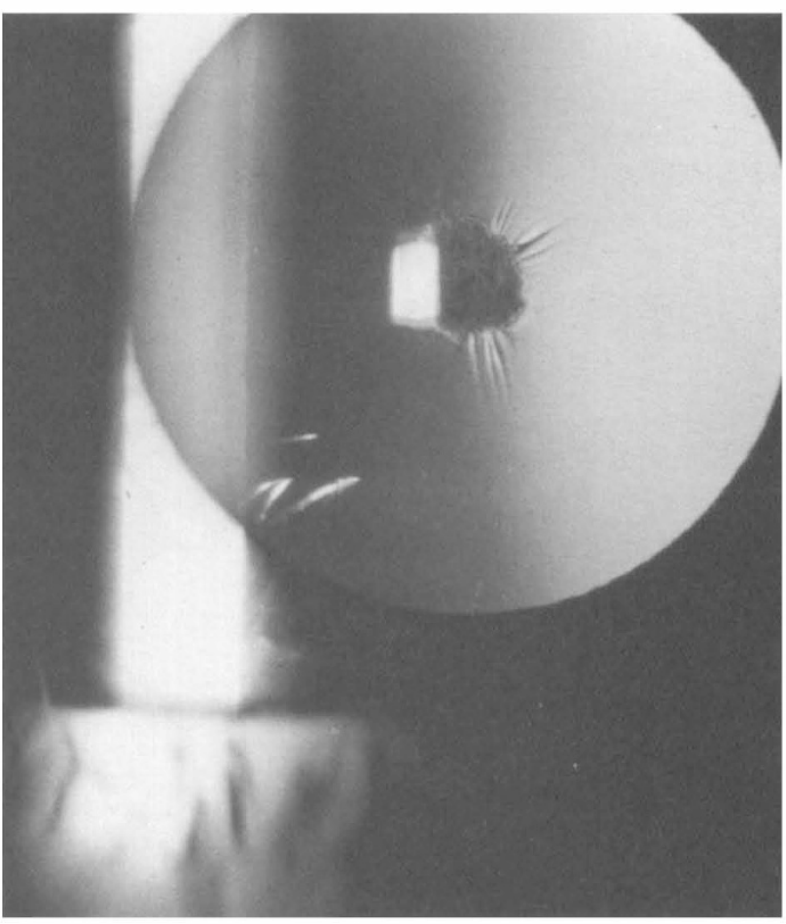

Fig. 3. Anterior polar cataract showing capsular wrinkles that are probably associated with the astigmatism that occurs in some cases. 
and although they are often not in themselves visually significant, they may be associated with refractive errors $^{122}$ (Fig. 3), amblyopia and strabismus. Usually static, they may occasionally progress ${ }^{123,124}$ and become visually significant. Some cases are inherited as an autosomal dominant trait, and they may be associated with cornea guttata. ${ }^{125,126}$

Anterior pyramidal cataracts probably also represent anomalies of lens vesicle detachment; they are larger axial opacities than the dot-like anterior polar cataracts, may even extend anteriorly and rarely fuse with the cornea. They are fibrous, and more likely to be visually significant and to progress than anterior polar cataracts. They may become detached ${ }^{127}$ and form an anterior chamber foreign body. ${ }^{128}$

Plaque-like anterior polar opacities are axial or eccentric opaque plaques associated with a persistent pupillary membrane (Fig. 4). Presumably they are caused by abnormalities of pupillary membrane regression.

Anterior subcapsular cataracts are usually associated with acquired disease such as uveitis, trauma, irradiation or atopic skin disease, but they may be part of a more widespread cataract. They may, rarely, be associated with anterior lenticonus such as that seen in Alport's syndrome.

Anterior lenticonus is most frequently encountered in association with Alport's syndrome of nephritic haematuria and deafness. The lenticonus may be a manifestation of a basement membrane disorder; ${ }^{129}$ it can be congenital and is found in about $10 \%$ of affected young children, ${ }^{130}$ but may increase in frequency with time up to $30 \%$. ${ }^{131}$

Mittendorf's dot represents the remains of the anterior end of the hyaloid artery. It appears as a small axial or paraxial grey-white dot opacity at the posterior apex of the lens, often associated with the thread-like remains of the hyaloid artery. It is visually insignificant unless it is large, when it may then represent a form of PHPV.

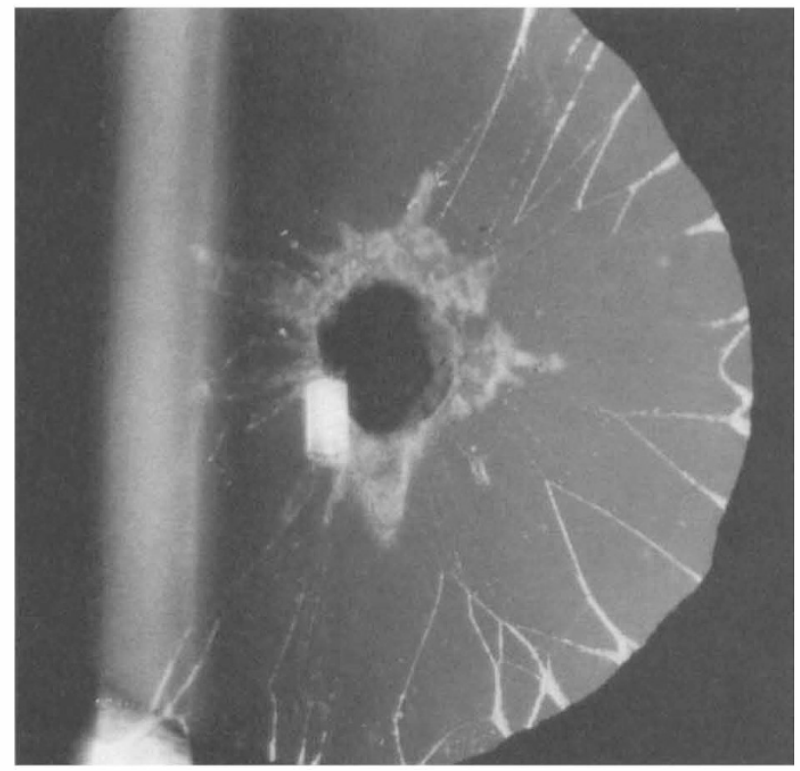

Fig. 4. Plaque-like anterior polar cataract showing its association with remnants of the pupillary membrane.
Posterior lenticonus or lentiglobus is a unilateral or bilateral and asymmetrical, thinning and posterior bowing of the posterior lens capsule which has variable effects on the adjacent lens cortex: sometimes it manifests as a high degree of astigmatism, often irregular, without cataract or as a progressive, localised opacity in the abnormal area. It may be present at birth ${ }^{132}$ or progress in the first months ${ }^{133}$ of life. It is not usually associated with any systemic disease. Amblyopia is frequently present; ${ }^{134}$ however, vision may be improved by postoperative occlusion, ${ }^{135}$ and because there is a possibility of the visual defect being acquired, surgery may still be indicated even in cases where one might normally expect a poor visual result. ${ }^{136}$ The visual results are generally better than with many other causes of infantile or congenital cataract. ${ }^{104}$ There is a localised thinning of the posterior capsule. ${ }^{137-141}$ Sometimes the junction between the lenticonic and the adjacent capsule is sharply defined and may be seen as a 'ring of fire' on slit-lamp examination. ${ }^{142}$ Presumably, the cause of the cataract is largely mechanical; as the capsule bows posteriorly there is progressive distortion of the lens fibres themselves, and cataract formation which can be rapid. Sometimes there may be a hyaloid remnant attached to the lenticonic area: ${ }^{137,143,144}$ the pathogenesis of these cases (Fig. 5) may be different from that of the majority without a hyaloid remnant. Although sporadic cases exist, many are inherited as an X-linked ${ }^{145,146}$ or autosomal dominant trait. $^{144-147}$

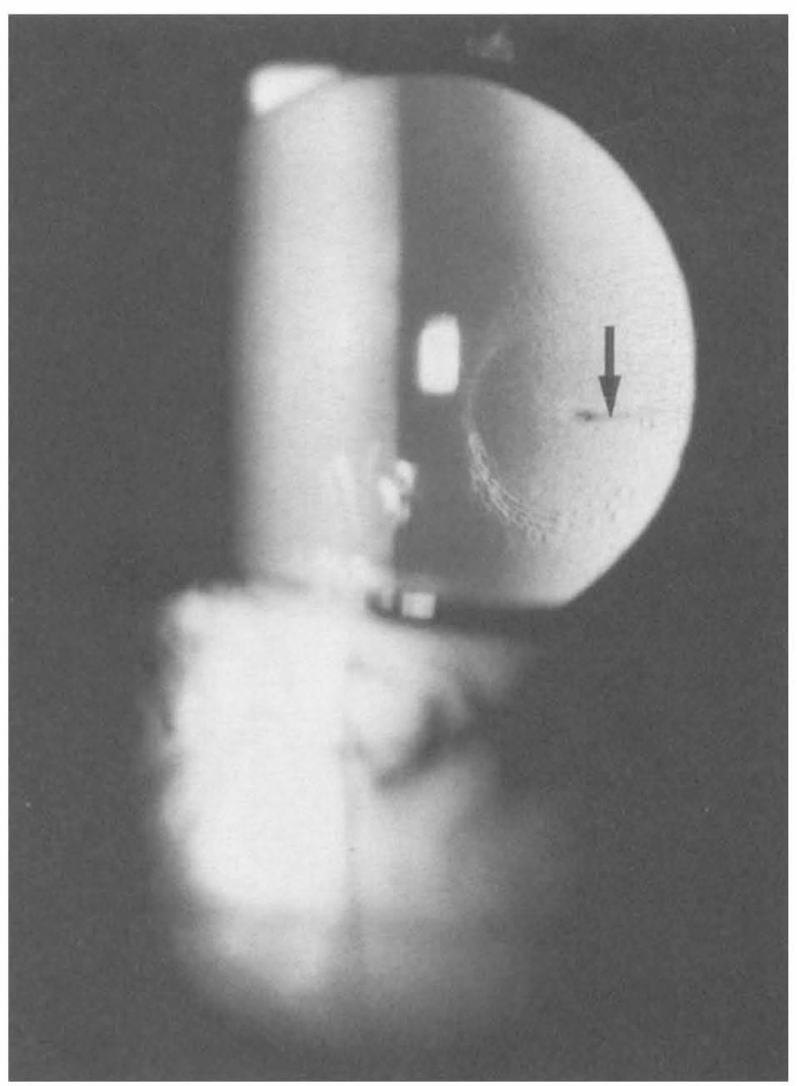

Fig. 5. Posterior lenticonus with attached hyaloid artery (arrow). 
Posterior lens reduplication is a rare congenital anomaly in which there is a small, distinctly separate, additional lens, usually cataractous, on the posterior pole of the normal lens (Fig. 6); it probably results from an abnormality of lens placode invagination, and needs to be distinguished from posterior lenticonus.

Lamellar or zonular cataracts are common forms ${ }^{148}$ involving one or more layers or zones of the lens. They are often inherited as an autosomal dominant trait. Typically, they are bilateral but slightly asymmetrical, and are composed of a layer of minute white dots in a single or more layers of the lens not involving the embryonic nucleus, but sometimes involving the fetal nucleus, and with clear cortex outside them. They are often incomplete, and they may have projections from their outer edges known as 'riders'. The visual prognosis, especially in partial cataract, is better than in many other morphological types; ${ }^{104,149}$ many cases can be managed conservatively. ${ }^{103,150}$ There is often a marked interocular and intrafamilial variability. ${ }^{107}$ They presumably are related to a transient disturbance of lens metabolism; although most usually no underlying cause is found, they may occur in cases of known transient metabolic disturbance, such as galactosaemia. ${ }^{151}$

Nuclear cataracts are opacities of the embryonic or fetal nucleus, similar to lamellar cataract, and often not highly visually significant. Vogt's anterior axial embryonic cataract is a visually insignificant group of opacities lying near, but posterior to, the anterior upright Y. Vogt ${ }^{152}$ thought that it may be remnants of primary lens fibres; Mann ${ }^{137}$ felt it was more closely related to sutural development. Crystalline nuclear cataracts have been described in association with an abnormality of the hair. $^{153}$

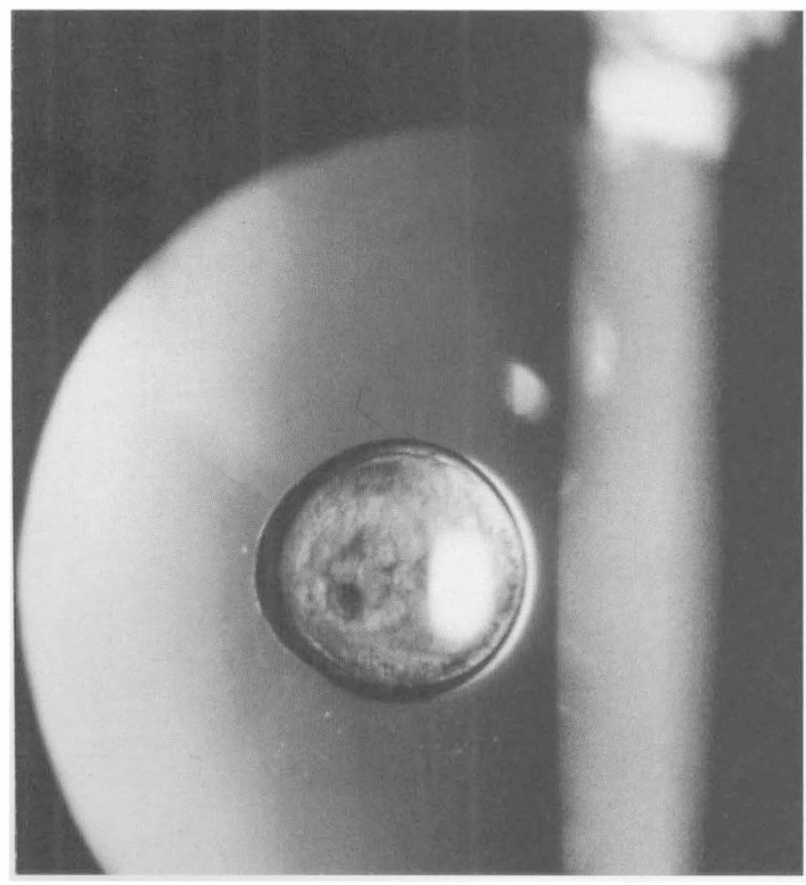

Fig. 6. Posterior lens reduplication showing a clearly defined cataractous 'blister' on the posterior surface of, but demarcated from, the lens. It remained static for 4 years.
Central pulverulent cataracts are composed of myriads of ('pulverised') tiny dots. They may be familial as in the autosomal dominant 'Whalsay' cataract, ${ }^{154}$ which affected descendants of a Dane, born in 1745, who immigrated to the Shetland Isles.

Nettleship and Ogilvie described the central pulverulent cataracts of the Coppock family in 1906: ${ }^{155}$ 'Our attention was originally drawn to the family by $\mathrm{Mr}$ Doyne who saw and described the first case, William Coppock, senior in 1888 at the Oxford Eye Hospital . . . The cataract is always very partial and circumscribed, sometimes being so slight as to require careful seeking ... a sharply defined circular disc placed deep in the lens between the nucleus and the posterior pole'. They distinguished it very carefully from lamellar cataract. Adams, ${ }^{156}$ also at the Oxford Eye Hospital, described a patient who was 'one of the original family': the cataract was not discoid, but central; this was confirmed by Rosen's ${ }^{157}$ slit-lamp photographs. There is frequently considerable intrafamilial variation ${ }^{85}$ (Fig. 7).

Oil-drop cataracts are classically seen in infants with galactosaemia. There is a central area of different refraction to the surrounding lens that looks like an oil droplet floating on water. If treated late or if the diet is not strictly adhered to, a lamellar opacity may develop. Other forms of cataract occur in galactosaemia including posterior subcapsular, small nuclear and cortical. ${ }^{158}$ They may regress if dietary control is good. ${ }^{158}$

Cortical cataract is unusual in childhood. A few families have been described with an autosomal dominant inheritance. ${ }^{85}$ The onset of the cataract may be post-natal - at least the visual defect may become significant after infancy. The nucleus is not involved.

Blue-dot, cerulean, coronary or punctate cataracts have a beautiful sky-blue or sea-green (cerulean) hue on slit-lamp microscopy; ${ }^{159}$ other colours may be seen, including red, brown and opalescent white. They are bilateral, largely stationary, and visually significant. They are often concentrated in the equatorial region of the lens, and they have a variably sized dot-like shape;

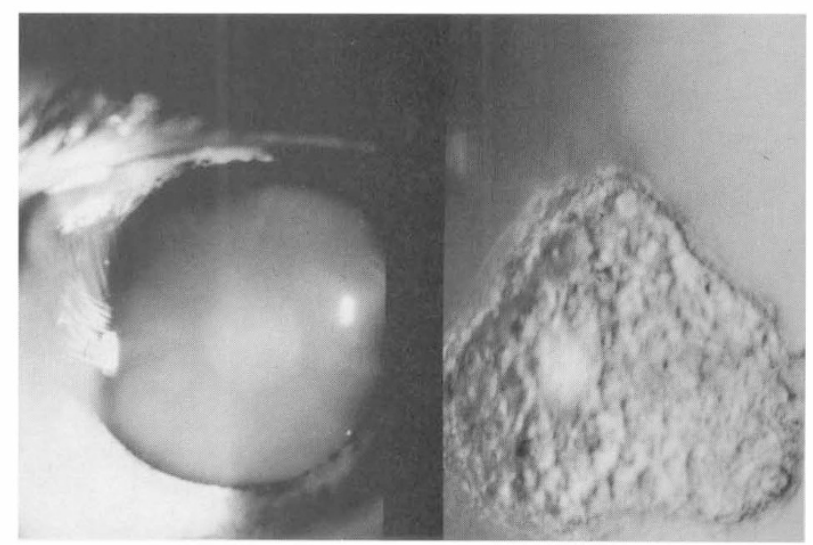

Fig. 7. Intrafamilial phenotypic variation in central pulverlent cataract. On the left is the cataract of the asymptomatic patient who was detected by screening; on the right is the posterior cortical cataract of her mother. 
sometimes they are elongated. Coronary cataracts are elongated or club-shaped cerulean opacities that form a ring around the equator.

Punctate lens opacities occur in 13-20\% of patients with Down's syndrome. ${ }^{160,161}$ The opacities occur in the peripheral cortex, and at the anterior and posterior poles, ${ }^{162}$ and they increase with age. They were thought to arise from excrescences of the capsule ${ }^{163,164}$ but a subsequent study has failed to corroborate this. ${ }^{165} \mathrm{In}$ carriers of Lowe's syndrome, punctate grey-white opacities occur in all layers of the cortex, but not in the nucleus; ${ }^{166-169}$ they increase in number with age, and since these opacities may be found in the normal population, their numbers must be compared with those in age-matched controls.

Sutural opacities around or involving the sutures are very common, and not usually visually significant. They are often familial and range from an increased density of the sutures to a variety of whitish or cerulean dots clustered around either or both sutures. They may progress, and form nuclear or central cataracts. ${ }^{170}$ Sometimes, sutural cataracts are the only manifestation of involvement in asymptomatic relatives. They may be inherited as an autosomal dominant or X-linked recessive $^{171}$ trait. They are rarely found in association with the sutures more peripheral to the $Y$ sutures.

Coralliform cataracts are usually static, central, complex cataracts that cut across normal anatomical boundaries, and are composed of multiple round or fusiform white or cerulean opacities. They are arranged in a coral-like, ${ }^{172}$ fusiform, or spindle-shaped fashion and they may be mainly axial. The anatomical arrangement suggests that they may be due to a primary abnormal arrangement of lens fibres. They are often visually insignificant, and can be inherited as an autosomal dominant trait. ${ }^{173,174}$

Wedge-shaped or sector cataracts occupy a sector of the lens, or if they are larger they are known as semilunar. They have been described in Conradi's syndrome, ${ }^{175}$ when they may represent an example of Lyonisation, and Stickler ${ }^{176-178}$ syndrome.

PHPV must be considered in any discussion of congenital, especially unilateral, cataract management. In 1840 Mackenzie $^{179}$ noted 'In some congenital cases we find the pupil widely dilated and round the cataract the appearances of a black zone, the lens and capsule being so small in consequence of impeded growth as to drag into view the ciliary processes'. The surgery consisted of couching or needling the membrane after lens discission: ${ }^{13}$ the visual results were not reported in detail! PHPV was characterised by Reese ${ }^{180}$ and more recently by Goldberg ${ }^{180 a}$ as a variable developmental abnormality of the primary vitreous and hyaloid vascular system. The eye is usually microphthalmic, there is a membrane of very variable extent and thickness behind, and usually inseparable from, the lens that is attached via the apices of its scalloped margins to a variable number of ciliary processes. The membrane itself is relatively avascular, but there are usually vessels that pass to the ciliary processes and the iris, and the hyaloid vascular system is present to a variable degree, but only occasionally is there significant flow: it is probably leakage from this vessel that causes intralenticular haemorrhage. ${ }^{181-183}$

The lens itself may be of a normal size, which gives rise to a shallow anterior chamber as the retrolental membrane shrinks and thrusts it forward; this occurs usually in the first months of life and may be progressive, giving rise to glaucoma. The lens may spontaneously reabsorb, ${ }^{108}$ but the eye is still at risk, if the membrane is thick, of dislocation of the ciliary body and hypotony. In one histopathological series ${ }^{184} 58 \%$ were unilateral without associated ocular anomalies, $31 \%$ unilateral, with ocular anomalies, and $11 \%$ were bilateral with ocular or systemic abnormalities. Systemic disease is so rare in unilateral PHPV as to make routine investigation unrewarding.

The indications for surgery are threefold: first, to prevent the complications of glaucoma and hypotony, second for cosmesis, and third for vision. It is known that, if treated early, the visual prognosis may be sufficiently good ${ }^{136,185}$ to warrant the arduous optical correction and occlusion regime that is the same as that for unilateral congenital cataract; the visual results are probably better in the milder cases.

\section{The untreated state}

What happens to untreated congenital cataracts? The shape of central cataracts is altered by the growing cortex $^{186}$ in that they are compacted at a decreasing rate with age, the eye remaining emmetropic despite changes in the parameters that determine refraction. ${ }^{187}$ Many cataracts are sufficiently mild and little changed by time that they can be managed conservatively. ${ }^{103,105,150,188}$ Often, in lamellar cataracts, the child is able to go through a normal education, perhaps with a little extra help, and it is the desire to obtain a driving licence that brings about the surgery.

Some cataracts progress rapidly; for instance, untreated galactosaemic oil-drop opacities become lamellar-like cataracts and, if treated, some of these cataracts may disappear, ${ }^{158,189-192}$ or at least fail to progress. ${ }^{193-195}$ Monitoring of galactosaemia dietary control by observation of the cataracts has been suggested. ${ }^{158}$ Many more progress very slowly.

In a small proportion of untreated cataracts spontaneous reabsorption takes place. ${ }^{4,117,179,196}$ due to leakage of lens material, degeneration, liquefaction and absorption leaving behind the capsular leaves with a variable amount of residual lens matter.

\section{Bilateral cataract \\ Aetiology}

There have been numerous excellent reviews of aetiology $60,66,148,197-200$ and the differential diagnosis, ${ }^{59,201}$ but since the incidence varies so much with the location of the investigator there can be few implications that can be gained from any one study, at 
any one time. Rubella, for instance, has nearly disappeared in developed countries but is still the main cause of cataract in others. The reader is referred to the papers cited above for a fuller discussion.

\section{Investigation and family history}

Ideally, the investigation of the child with bilateral congenital cataracts is undertaken by the ophthalmologist and a paediatrician, and sometimes a geneticist, a dysmorphologist, a counsellor or vision development team organiser and a developmental paediatrician. The education authorities may be involved early. The first role of the ophthalmologist is to see whether the problem is a purely ocular one; posterior lenticonus, unilateral PHPV and most familial cataracts rarely require the involvement of a paediatrician. The parents and any siblings should be examined, preferably dilated and with a slit-lamp, even in the absence of a positive family history.

The paediatrician will need to assess the overall development of the child, and look for the presence of any dysmorphic signs, or signs of metabolic or other disease. There is no need to carry out a battery of biochemical or other tests in every case; further investigations should be directed appropriately by the paediatrician There are, however, some investigations that are useful as a routine such as urine amino acids, reducing substances and organic acids, and blood electrolytes, amino acids and fasting lipids. Some cases may require bone $\mathrm{X}$-rays (Conradi's syndrome), chromosome analysis (dysmorphic children), galactose enzymes, virus antibodies or cultures of the lens aspirate.

\section{Visual assessment and the indications for treatment}

When the visual defect in a child with congenital cataract is severe enough to interfere significantly with visual development then surgery and post-operative optical treatment, together with occlusion therapy, if indicated, are necessary. However, if the vision of the infant is good enough, active management is best postponed until the child is older, as it may be possible at the later age to carry out a more satisfactory optical correction as the change in power of an eye becomes less. To be sure of the best course for each individual, careful, and sometimes repeated, visual assessment is mandatory. ${ }^{202,203}$

There are many congenital cases where the state of the vision is obvious; if the cataract is dense and large, or total, then there is no doubt that surgical treatment is necessary. In partial cataract, the assessment is much more difficult, and clinical observation is still the most important and reliable method of determining whether treatment is in the best interests of the child. Although qualitative, it is reliable and can even be used to monitor occlusion post-operatively. ${ }^{204}$

The fixation pattern of each eye - whether it is central, steady and maintained, whether there is nystagmus and whether the child has fixation and refixation reflexes appropriate for his or her age - are all observations that are used as the basis for the decision whether or not to operate. An infant with a total cataract, especially if it is acquired, may fix a light normally, despite being effectively blind to solid objects. It is most important not to be influenced unduly by the density or extent of the cataract on ophthalmoscopy: it is very misleading and can either under- or over-estimate vision.

There can be no hard and fast rules as to whether surgery is indicated, and the principle should be whether or not there is sufficient visual defect to significantly interfere with a reasonably normal visual development. If there is any doubt it is always better to reassess the situation after a short period.

There are two main ways of measuring acuity in preverbal children. These are particularly useful in carrying out serial measurements in the management of the post-operative occlusion, but may also be used in pre-operative assessment. Visually Evoked Cortical Potentials (VEPs) to transient patterned stimuli, ${ }^{19,205-207}$ or 'steady-state' or 'swept' VEPs ${ }^{207,208}$ have been successfully used to measure pre- and post-operative acuities; although they suffer the disadvantages of cost and requiring very substantial expertise, they are the only way of measuring vision without the need to observe eye movements, and they may be more suitable for less co-operative and less attentive infants. Flash VEPs may be useful in complete cataract to establish the gross integrity of the neural visual pathways. Forced Choice Preferential Looking (FPL) is now commonly used in clinics managing patients with congenital cataract. $^{209-212}$ The method requires meticulous technique if it is to be reliable, but with appropriate training, it can be performed by a wide variety of personnel. It is relatively inexpensive.

\section{Conservative management}

Because very many individuals with congenital cataract have a good prognosis untreated, it is vital that they should not have surgery without due caution and assessment. The use of mydriatics may be helpful in some cases, especially during re-evaluation, but in the long-term the effects on accommodation and glare are significant limiting factors. ${ }^{105}$ Optical iridectomy was popular previously ${ }^{103,213-215}$ because it avoided aphakia and its correction, usually by spectacles; it was most useful in partial cataracts. ${ }^{213}$ As methods of optical correction became better, the relative disadvantages of iridectomy therefore became greater, and it became less popular also because the visual results were less than satisfactory, ${ }^{105,216,217}$ probably because paraxial light rays through the peripheral parts of the lens used after the iridectomy are optically inferior to axial ones. ${ }^{218}$

\section{Surgery \\ Bilateral synchronous or asynchronous surgery?}

In some centres bilateral, synchronous cataract surgery has been routine, ${ }^{219}$ and Guo et al. ${ }^{220}$ felt that bilateral 
synchronous cataract surgery had the benefits of reducing the anaesthetic risks, reducing hospital in-patient time and costs and allowing earlier optical correction, reducing interocular differences. It is generally felt, however, that the risk of bilateral synchronous endophthalmitis is much greater than the risks of anaesthesia, ${ }^{221-223}$ and the cost savings and optical benefits are not important if there are just a few days between operations. Bilateral, synchronous surgery should therefore be reserved for those rare cases that are a significant anaesthetic risk even in a sophisticated paediatric service. $^{224}$

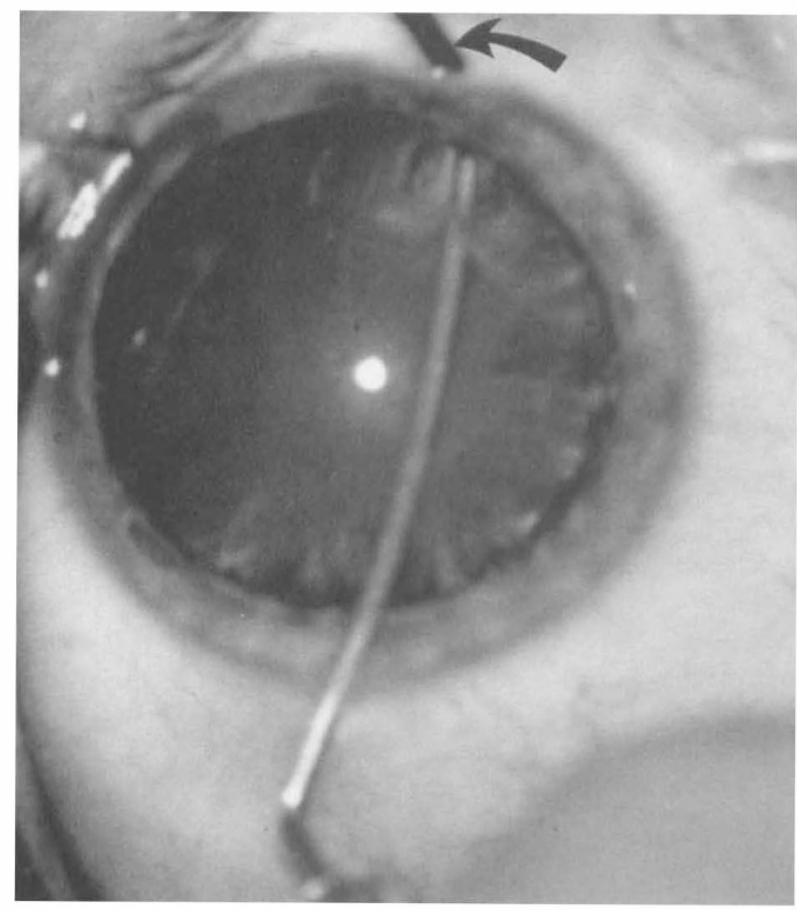

(a)

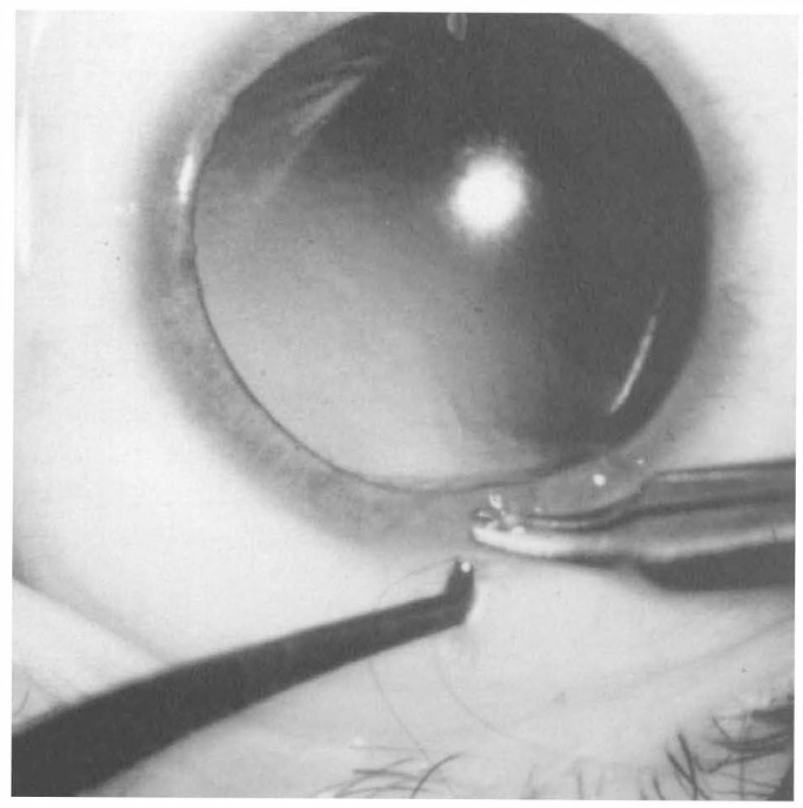

(c)

\section{Operation sequence in bilateral cataract}

Bouzas $^{29}$ noted that the visual results in one eye in bilateral cataract were worse if the other eye was operated much earlier. Even a short interval between the operations on the two eyes ${ }^{28,225}$ may result in significant differences in the final acuities. This difference can be mitigated by synchronous surgery ${ }^{219,220}$ or, more safely, by occluding both eyes until the second eye is operated.

\section{Lens aspiration}

Lens aspiration became used extensively after it was popularised by Scheie in $1960 .{ }^{9,226}$ Scheie's technique was to use a 19 gauge thin-walled needle with a rounded point;

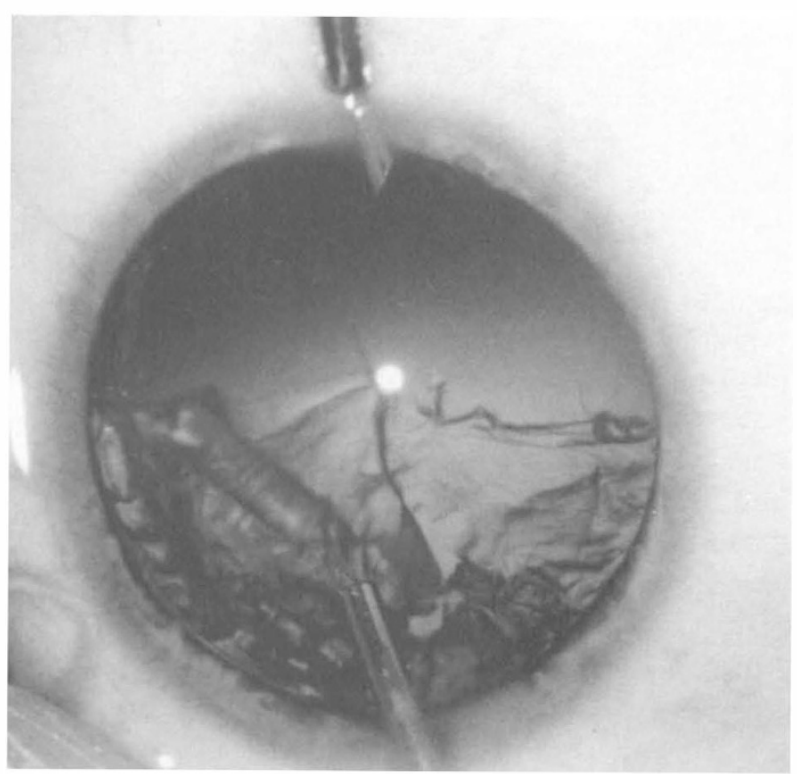

(b)

Fig. 8. Simples lens aspiration. (a) A wide 'can-opener' anterior capsulotomy is made to remove as much of the anterior capsule as possible. The arrow indicates a small self-retaining infusion cannula. (b) The lens cortex and nucleus are aspirated through a blunt-ended cannula. (c) A clear posterior capsule is left; a primary posterior capsulotomy or capsulorhexis can be performed at this stage. Even if clear, the posterior capsule will opacify in nearly all infants. 


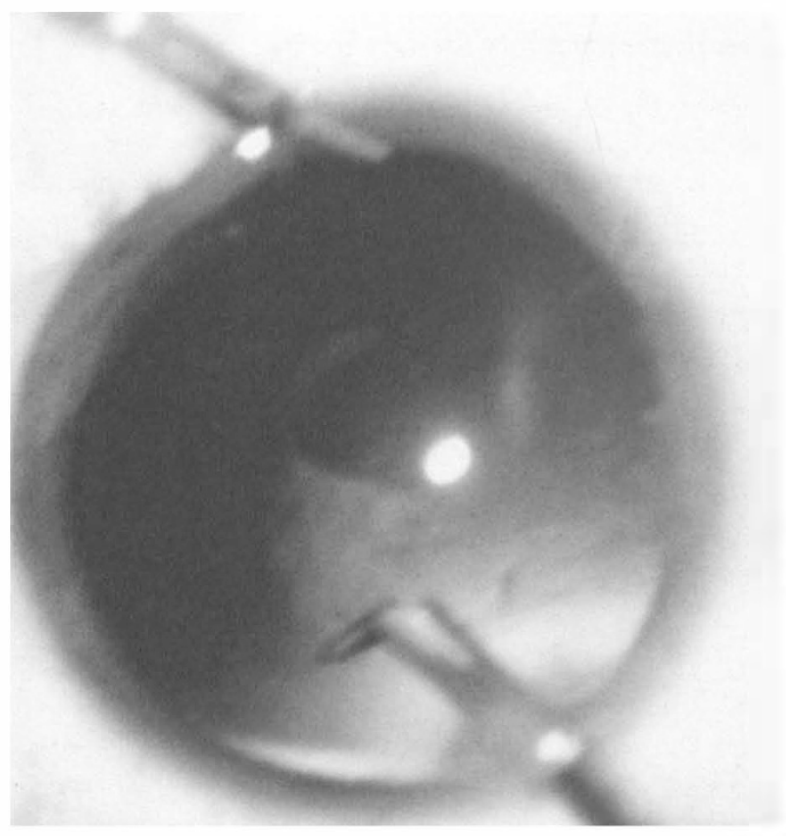

Fig. 9. A posterior capsule plaque is peeled off the posterior capsule to leave a clear axis.

he just aspirated, replacing the aqueous if necessary. There have been many improvements in this technique, ${ }_{1}^{10,216,227}$ particularly the addition of one or other form of irrigating cannula to maintain the anterior chamber (Fig. 8), and the routine use of the operating microscope.

The main problem with aspiration is that the posterior capsule is left behind, and it becomes opaque, even if it is meticulously cleared of any membranes and cleaned (Fig. 9), leading to amblyopia and necessitating repeated surgery. ${ }^{228}$ Capsulotomy can be done at the time of the primary surgery, either using a knife-needle ${ }^{10}$ or with a vitrectomy machine. ${ }^{229,230}$ In small infants there is a risk of posterior synechiae formation and iris bombé. This may cause glaucoma, and a peripheral iridectomy is recommended by some ${ }^{231}$ to prevent this; most recommend that in infants of less than 18 months old, a lensectomy, without irridectomy, is performed. ${ }^{232}$

The most frequent indication for lens aspiration today is in an older infant in whom the surgeon may not wish to use an intraocular lens due to the potential growth of the eye, or a likely lack of co-operation with postoperative follow-up. Below the age of 1 year to 18 months, lensectomy is probably the preferred technique. ${ }^{228,232}$ Long-term follow-up suggests that the complication rate of simple lens aspiration is low. ${ }^{10,233}$

\section{Lensectomy}

As vitrectomy machines came into common use in the late 1970s they were used to get over the main problems of lens aspiration: capsule opacification and vitreous strands through primary capsulotomies. The former was a significant cause of amblyopia in infants, in whom the opacification was most rapid.

An anterior approach (trans-corneal) $228,229,234-237$ was used because it was felt that an adequate exposure could be obtained in all cases by modifications of the surgical

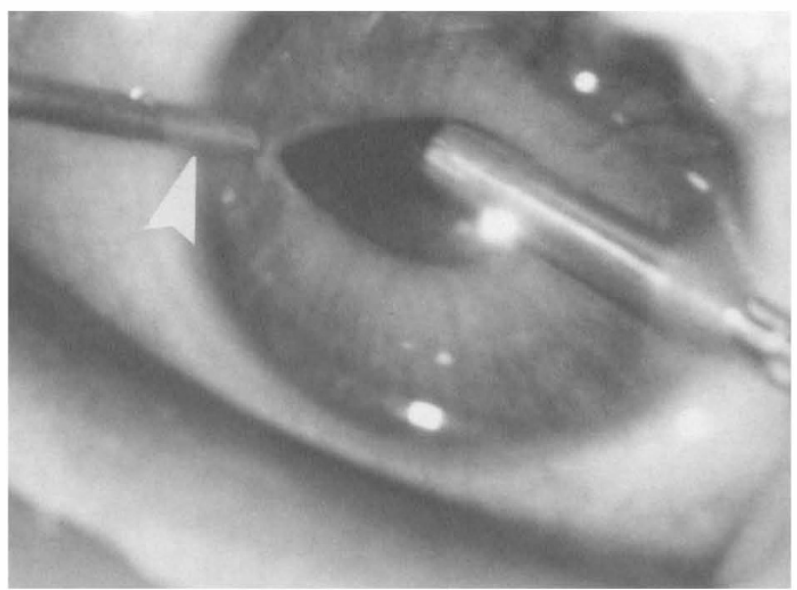

(a)

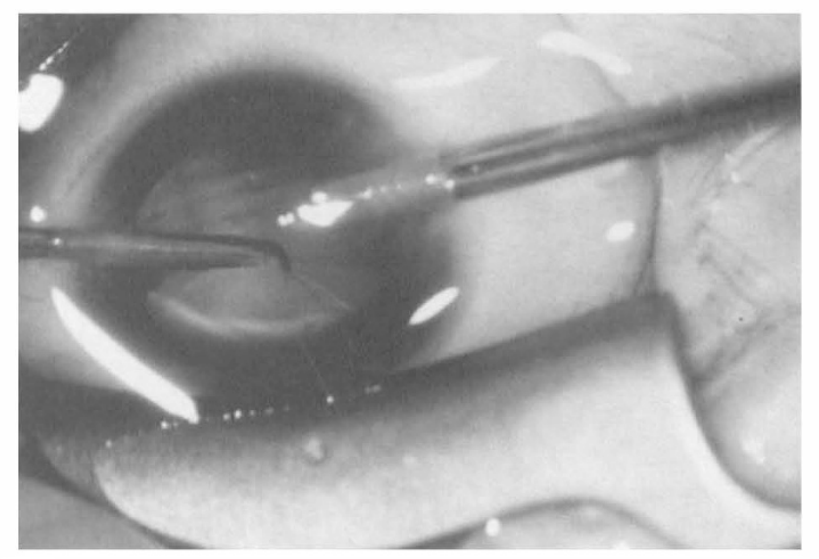

(b)

Fig. 10. Bi-manual lensectomy. (a) The irrigating cystitome is being used to retract the iris in order to expose the parts of the lens covered by the iris in a case where the pupil has failed to dilate. (b) The irrigating cystitome is being used to deliver lens material to the vitrectomy machine.

technique (Fig. 10). Earlier posterior approach (transscleral) techniques were based on adult anatomy with the entry being made $4 \mathrm{~mm}$ behind the limbus. ${ }^{238}$ It soon became clear that this gave rise to damage to the retina and vitreous base in infants, so empirically ${ }^{239-243}$ or based on anatomical studies ${ }^{244}$ a pars plicata approach was adopted, with the entry $1.5-2.5 \mathrm{~mm}$ behind the limbus.

The advantage of lensectomy was that the visual axis was cleared permanently and re-operation for an occluded axis was rare, ${ }^{228}$ although secondary cataract was recorded even after capsulectomy and anterior vitrectomy. ${ }^{245}$

\section{Complications of surgery \\ Operative and immediately post-operative complications}

Endophthalmitis following intraocular surgery in children is not common, but a survey of over 500 paediatric ophthalmologists ${ }^{223}$ suggested an incidence of 7 per 10000 cases. The infection was diagnosed by the third post-operative day in $82 \%$ of cases, and an organism was found in $65 \%$ of cases. Nasolacrimal duct 
obstruction and upper respiratory tract infections are significant predisposing factors ${ }^{222}$ and the visual prognosis is poor, $65 \%$ having no light perception.

Taking inadvertent small 'bites' at the pupil margin is quite common but it is probably not very important visually; larger ones may be. Posterior synechiae occur, especially after infant lens aspiration, in PHPV, and in intraocular lens implantation. ${ }^{246,247}$ Many pupils are small in congenital cataracts, and the necessary surgical manipulation or stretching by iris hooks may damage the sphincter muscle.

Vitreous strands or 'wicks' are not unusual, even with careful surgical technique, because they may be difficult to detect and if the baby cries in the early post-operative period the chances of vitreous prolapse increase.

A knuckle or iris often becomes attached to the incision site, giving a distortion of the pupil; this is due to wound leakage in the immediate post-operative period, enhanced by crying. Larger iris prolapses can only occur with adult surgical-type incisions.

Transient flame-shaped retinal haemorrhages are not infrequent after lensectomy; ${ }^{248,249}$ they are probably due to hypotony and vitreous traction.

Hyphaema is not uncommon in minor degrees but it is sufficiently serious to figure in some series that discuss surgical complications. ${ }^{20}$ It may be a prominent part of the process that leads to phthisis bulbi. ${ }^{250}$ Intralenticular haemorrhage suggests that PHPV is the underlying diagnosis.

Endothelial cell loss of up to $10 \%{ }^{251-254}$ may occur, irrespective of the method of surgery. ${ }^{252}$ Persistent corneal oedema was much more frequently seen when rubella was more common. ${ }^{255}$ Endothelial cell loss may be severe with the use of some types of intraocular lenses. ${ }^{256}$

Vitreous loss of lens material (Fig. 11) needs to be detected by fundoscopy at the end of the procedure, and treated immediately by vitrectomy.

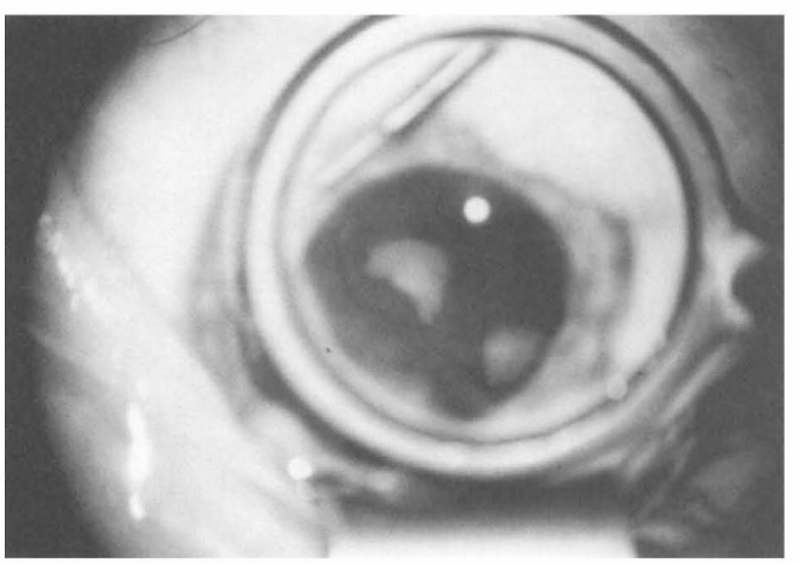

Fig. 11. Vitreous loss of lens material. Two white, fluffy lumps can be seen adjacent to the inferior temporal vascular arcade. Removal by vitrectomy and aspiration should be carried out to avoid inflammatory consequences.

\section{Later post-operative complications}

Where the posterior capsule is left intact in children, the visual axis will become obscured in the majority, ${ }^{213,228,257,258}$ with potentially serious effects on visual development.

There are two main types of posterior capsule opacification (PCO). In the first there is a rapid fibrosis from metaplasia of the epithelial cells that line the lens capsule. ${ }^{259-262}$ The second form of opacification ${ }^{260}$ is due to more gradual proliferation of equatorial lens epithelial cells that form the commonly found 'pearls' that may completely cover the posterior capsule. A Soemmerring's ring is formed when the proliferating lens epithelial cells are enclosed by both the anterior and posterior capsules. ${ }^{260}$ Clinical observation suggests that PCO is more rapid and severe if the eye is inflamed postoperatively, but human lens epithelial cell proliferation occurs in a protein-free medium as well as in one with added protein, ${ }^{263}$ suggested that inflammation is not essential for PCO.

PCO represents one of the major problems in congenital cataract management; ${ }^{264}$ it can be avoided by surgical technique, or treated. A lensectomy usually, but not always, avoids the need for surgery for secondary cataract, but leaving a substantial proportion of the membrane at the end of the operation improves the possibility of using a secondary intraocular lens at a later date, and disturbs the posterior segment less. Leaving the capsule intact, but performing a capsulectomy at the end of the procedure, with or without a vitrectomy, is one choice. ${ }^{228-230,235, ~ 265-267 ~ P o s t e r i o r ~ c a p s u l o r h e x i s ~(F i g . ~ 12) ~}$ has become more widely used, greatly aided by viscoelastic substances. It may be combined with a small vitrectomy and the lens optic may be slipped behind the posterior capsulorhexis ${ }^{258,268}$ as a way of reducing opacification.

The alternative to prevention, and the management of those in whom prevention has been unsuccessful, is to perform a secondary capsulotomy by needling, YAG laser $^{269,270}$ or by an anterior or posterior ${ }^{238}$ approach using a vitrectomy machine.

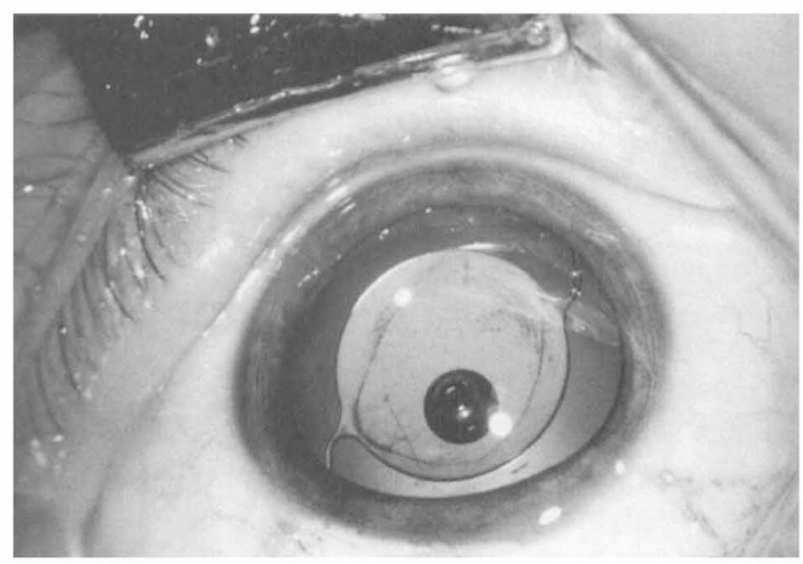

Fig. 12. An intraocular lens 'in-the-bag' with an anterior and (rather large) posterior capsulorhexis. 
Table 2. The incidence of glaucoma as a complication of congenital cataract

\begin{tabular}{llr}
\hline Series & Operation & Incidence of glaucoma \\
\hline Hammami $(1972)^{215}$ & Linear extraction, discission, or intracapsular & $6.5 \%$ \\
Rice $(1977)^{10}$ & Lens aspiration & $0.9 \%$ \\
Chrousos $(1984)^{257}$ & Lens aspiration & $6.1 \%$ \\
Keech $(1989)^{267}$ & Lens aspiration or lensectomy & $11 \%$ \\
Simon et al. $(1991)^{277}$ & Lensectomy & $24 \%$ \\
Robb and Peterson $(1992)^{278}$ & Various & $27 \%+$ \\
Schrader et al. $(1994)^{279}$ & Pars plana lensectomy & $4.1 \%$ \\
Biglan et al. $(1997)^{280}$ & Cataract + secondary IOL & $7.1 \%$ \\
\hline
\end{tabular}

Early papers on retinal detachment following childhood aphakia were influenced by the very poor prognosis in nearly every case and it is still difficult to get a reliable insight into the incidence due to the long latent period and the poor long-term follow-up in all series. The incidence is between $1 \%$ and $10 \% .^{215,267,271,272}$ The latent period (the interval between the cataract surgery and the detachment) is long at, around 30 years, ${ }^{273-275}$ and although basal vitreous gel incarceration ${ }^{276}$ was a concern after lensectomy, it has not proved to be a significant problem yet. Although anatomical success is good, the visual results are worse than in many other types of detachment.

Glaucoma is the most frequent serious complication encountered in the management of congenital cataract, but there is no very accurate estimate of the incidence. The wide variation in the results (Table 2 ) suggests a low rate of detection in some series, variations in incidence with different surgical techniques and with different timing of surgery.

Children with aphakic glaucoma present, if they have not been detected by screening, because of the appearance of corneal clouding, pain and redness, or because of the appearances associated with shallowing of the anterior chamber in pupil block. The eye may enlarge and become buphthalmic, but often this enlargement is subtle and is only shown as an excessive loss of hypermetropia, ${ }^{281}$ this loss of hypermetropia is normal in aphakic children, so it is important to monitor both corneal diameter, the state of the optic disc and intraocular pressure.

There are various ways in which glaucoma can occur:

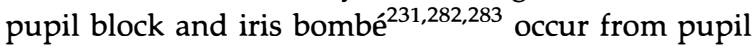
occlusion by vitreous, secondary membranes or synechiae. Glaucoma is rare after modern intraocular lens implantation; ${ }^{265,284-286}$ it may be, however, that this is due to selection bias: very few young infants and very few abnormal eyes are implanted, and, it is these eyes that are particularly prone to glaucoma. Pseudophakic malignant glaucoma ${ }^{287}$ has been described. Rapid lens swelling following discission ${ }^{288,289}$ was one of the main reasons why this procedure was abandoned and Treacher Collins ${ }^{137}$ knew that needling of Morgagnian cataract led to glaucoma; this complication cannot occur after an adequate removal of lens material by aspiration or lensectomy. There may be a familial predisposition or an anterior segment anomaly. ${ }^{290,291}$ Chronic open angle glaucoma is probably the most common form, comprising $79.7 \%$ of Asrani and Wilensky's series of 64 affected eyes. ${ }^{292}$ The cause is not certain, although it may be more frequent in microcornea, ${ }^{104,293,294}$ with small pupils, ${ }^{293}$ and with surgery before 1 year of age. ${ }^{267,278,293}$ The cause may be an accumulation of lens material in the angle. ${ }^{295}$ It is unlikely that the use of steroids is a significant factor in many cases because they are used for only a short time. Although the glaucoma may be associated with pre-operative factors, ${ }^{267,290}$ it seems likely that the surgery itself plays a major role; it occurred in only the operated eye of a patient with bilateral cataract. ${ }^{277}$ Vitreous may cause glaucoma by pupil block, ${ }^{282,288}$ perhaps aided by premature posterior vitreous detachment, explaining some cases that occur months or years after the initial surgery. The presence of large amounts of vitreous in the anterior chamber, spreading over the iris, may cause aqueous outflow defects. Glaucoma may be less common in patients who have had a lensectomy/vitrectomy. ${ }^{292}$ Lens-induced uveitis and glaucoma are rare. ${ }^{296,297}$

All aphakic children should be considered as being at risk for life. In the first years examinations under anaesthetic may be indicated; many patients can be followed by non-contact tonometry, observation of the optic disc, corneal diameter measurement, and ultrasound and refraction to monitor eye growth, before full glaucoma monitoring is instituted.

Although one paper ${ }^{298}$ tentatively suggested that cystoid macular oedema may be an important cause of visual morbidity after congenital cataract surgery, especially lensectomy, the incidence is now thought to be considerably less than $10 \%{ }^{243,299-302}$

Post-operative inflammation, leading to a high incidence of phthisis bulbi, occurred in the congenital rubella syndrome; ${ }^{226,303}$ the high incidence was reduced once it was realised that the virus remained in the lens for many years post-operatively ${ }^{304-306}$ and subsequent surgery included more complete aspiration and steroid cover. ${ }^{307-309}$ Chronic post-operative inflammation in relatively mild forms is not uncommon, Jameson et al. ${ }^{310}$ found it was less common in children up to 1 year, but personal experience suggests that it may be more common in younger patients or at least that inflammatory complications are less frequent in older children.

In infants, even with careful technique, nonabsorbable sutures become loose very frequently and need to be removed to prevent their becoming a focus for infection. They can be removed routinely from the first 
operated eye when the second eye is operated, or if there is another anaesthetic for any reason, but most surgeons now use absorbable sutures routinely.

\section{Optical correction}

\section{Introduction: the changing visual environment}

It has been known for 20 years that, experimentally, immature eyes can be made myopic by manipulating their visual environment ${ }^{311-317}$ and that humans may have the same effects from disease. ${ }^{318-320}$ Gordon and Donzis ${ }^{187}$ established that there is normally a substantial decrease in the power of the eye in the first years of life, particularly the first 2 or 3 years. It was not surprising, therefore, that Morris et al. ${ }^{321}$ (Fig. 13) found that there was a steady and significant decrease in the power of the contact lenses used to fully optically correct their infant patients' aphakic eyes as they grew. Other studies confirmed this myopic shift. ${ }^{316,322,323}$ It is almost universal and usually greater in unilateral cases; 316,324 this effect also occurs in pseudophakic eyes ${ }^{325-327}$ although in humans ${ }^{328,329}$ and in monkeys ${ }^{246}$ the effect may be less marked than in aphakic eyes. This refractive change has to be taken into account if the amblyopia is to be managed optimally.

\section{Spectacles}

'The child is very awkward in using convex glasses, and extremely unwilling to wear them. The early use of them is inexpedient'. ${ }^{4}$ Saunders was, unusually, wrong: spectacles can be worn at any age, they are not unduly expensive, they can be changed readily as the child grows, they are safe, their magnifying effect may improve the child's acuity and make microphthalmic eyes appear a more normal size. Spectacles can be the only form of optical correction that is available in a community, ${ }^{330,331}$ and most children using contact lenses should have a pair of aphakic glasses as a 'spare', for when they are not able to use contact lenses. A child wearing contact lenses, or with an intraocular lens, will need bifocals if his or her acuity is good enough.
Spectacles, however, have important disadvantages: an infant's ears and nose are often too insubstantial to support aphakic glasses, and they also have optical and cosmetic disadvantages.

\section{Contact lenses}

Contact lenses were infrequently used to correct aphakic children before the 1960s. In England, the problem was addressed by Mr Montague Ruben, at Moorfields Eye Hospital, who had already shown an interest in contact lenses for infants. ${ }^{332}$ He collaborated with the manufacturers of the lathes used to make hydrophilic lenses so that they were able to cut at previously unavailable radii, and a technician was employed to make the lenses specially for infants and young children. These lenses were used extensively, often on a continuous-wear basis, and the early results were encouraging. ${ }^{28,333}$ In North America, hydrophilic lenses were not so readily available and most of the early lenses were rigid forms: many were successful. ${ }^{17,334-336}$

The effectiveness of contact lenses in the management of amblyopia is emphasised by the fact that in many units specialising in the correction of infant aphakia rates of successful wear for the critical years of visual development approach $90 \% .{ }^{337-342}$ This still makes contact lenses the treatment of choice for infant (defined as a child in the phase of ocular and visual development) aphakia, ${ }^{342,343}$ and the standard against which other methods of optical correction should be compared before they are used.

Contact lenses have advantages in the correction of infant aphakia; ${ }^{344}$ the parameters can readily be changed. Morris et al. ${ }^{321}$ found that the contact lenses, used to fully correct aphakic infants, reduced in power very substantially in the first years of life; this myopic shift has been confirmed in other series of patients treated with contact lenses. ${ }^{322,323,345}$ They are safe, ${ }^{339-341,346-348}$ probably more safe than intraocular lenses. ${ }^{349}$ They can be used in combination with spectacles for a near addition and to correct aniseikonia. ${ }^{350}$

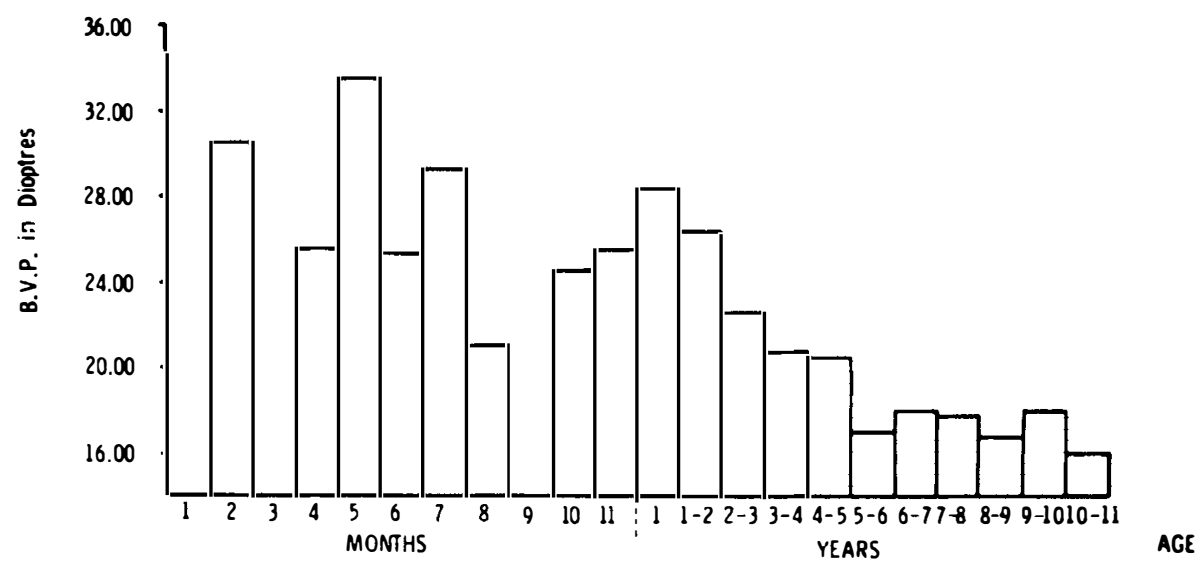

Fig. 13. The changes in back vertex power (B.V.P.) of aphakic contact lenses in relation to age. The changes are most marked in the first 2 years of life, underlining the need for any form of optical correction to take a continually changing refraction into account. From Morris et al. ${ }^{321}$ 
There are, however, a number of risks and disadvantages: hypoxic keratitis, ${ }^{351,352}$ infective keratitis, ${ }^{339}$ and red eyes without ulceration ${ }^{339}$ which are usually caused by chronic hypoxia or loose sutures. Corneal pannus of a millimetre or more ${ }^{339,346}$ suggests hypoxia; changing to a rigid gas-permeable lens from an extended-wear lens is effective. ${ }^{353}$ Increased corneal thickness occurs but human endothelium studies have not shown significant changes associated with contact lens wear, ${ }^{347}$ despite suggestive changes in infant primates. ${ }^{354}$ Contact lens fitting and tolerance problems, difficulties with occlusion, and high turnover of lenses may be a source of failure..$^{27,339,340}$ The costs can be substantial, especially if the rate of lens turnover is high, if there are complications requiring frequent outpatient visits or admission to hospital, or if the parents live far from the contact lens practitioner, and have to miss work to come for consultations. In 1990 the cost of lenses and solutions in the UK was $£ 187$ per year. ${ }^{339}$ Contact lenses are difficult to wear if there is external eye disease (as is frequent in Down's syndrome), if the eye is dry, ${ }^{355}$ or in microphthalmic eyes or eyes with corneal anomalies.

\section{Epikeratophakia}

Early attempts ${ }^{356,357}$ were accompanied by failure rates of up to $30 \%$ but success rates quickly improved. ${ }^{358-361}$ The Committee on Ophthalmic Procedure Assessment ${ }^{362}$ found that the refractive prediction was poor overall, there may be a significant time before the graft clears, making the treatment of amblyopia more difficult, and visual acuity after grafting may not improve adequately. ${ }^{361}$ Technical success rates in young children, with all that that implies for amblyopia, are lower $-63 \%$ in one series ${ }^{359}$ - and there is a significant myopic shift in the first years of life. ${ }^{359,363}$

Epikeratophakia, therefore, has rather special indications in patients with congenital cataract. It may be indicated when there is contact lens failure in the older monocular aphake who is less susceptible to amblyopia, or as an alternative to primary or secondary intraocular lenses in older bilateral aphakes who are contact lens and spectacle intolerant. Elsas ${ }^{23}$ made the very relevant point: 'The critical factor in getting good vision following monocular cataract extraction was the patient's willingness to patch the better eye, not the method of correction of the refractive error'.

\section{Primary intraocular lenses}

As the early published reports of intraocular lens (IOL) surgery indicated, ${ }^{364-369}$ there is not any technical problem with the implantation process, but with the management of amblyopia ${ }^{370}$ and the short- and longterm complications. Many of these early reports paid not even lip-service to the amblyopia question, and there is still a tendency to regard IOL implantation as a technical problem and an end in itself, not a part of the management of amblyopia. ${ }^{371}$

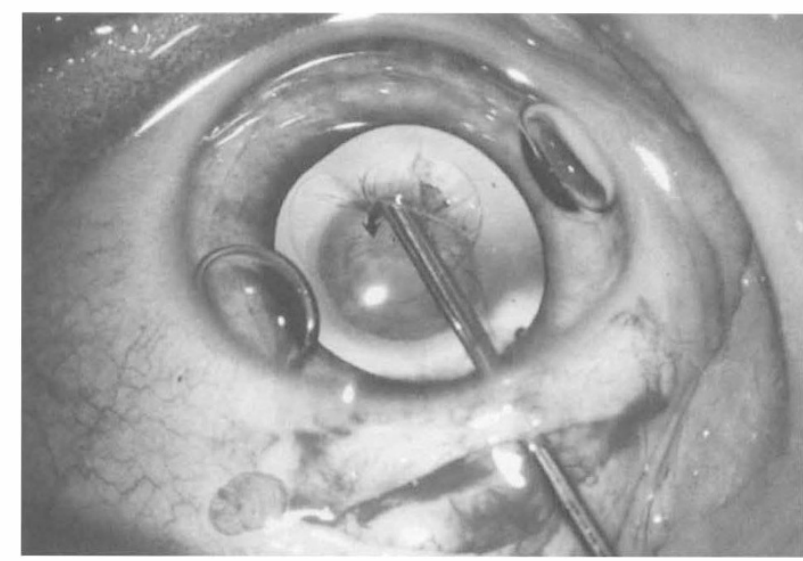

Fig. 14. Anterior capsulorhexis. The capsulorhexis is proceeding from left to right and is extending too far towards the equator of the lens; the forceps are applying force in the direction of the arrow. The infant lens capsule is very much more elastic than the adult's and the forces needed to produce a small, round, capsulorhexis must be vectored differently, often at more than a right angle to the intended direction.

For safe IOL implantation in children, a number of factors need to be taken into account: the lens needs to last the lifetime of the child, say 80 years for an infant. ${ }^{201}$ Although polymethylmethacrylate (PMMA) lenses in one form or another have been in use for decades and are known to be safe, their use combined with nylon loops has led to problems. ${ }^{372}$ Similarly, some flexible lenses were widely used for children in the 1980 s $^{349,373,374}$ only to be withdrawn in the early 1990s. New materials may make implantation easier, or enable a small incision to be used, ${ }^{328}$ but one must be sure of its likely lifespan as removal of a lens is a major intraocular procedure. Onepiece PMMA lenses are currently the most used lenses.

The implant needs to be of an appropriate size for the age and eye-size of the patient. ${ }^{375}$ Many would be cautious about using an IOL in a microphthalmic eye, ${ }^{376}$ whatever the size of the optic and haptics.

Anterior chamber lenses are easily implanted but have an unacceptably high complication rate. ${ }^{377-380}$ Today, an 'in-the-bag' technique, through a capsulorhexis that is smaller than the IOL optic diameter (Figs. 14, 15), is the favoured option by nearly all surgeons; ${ }^{201,285,329,381}$ a few believe that a sulcus-fixated lens is adequate.

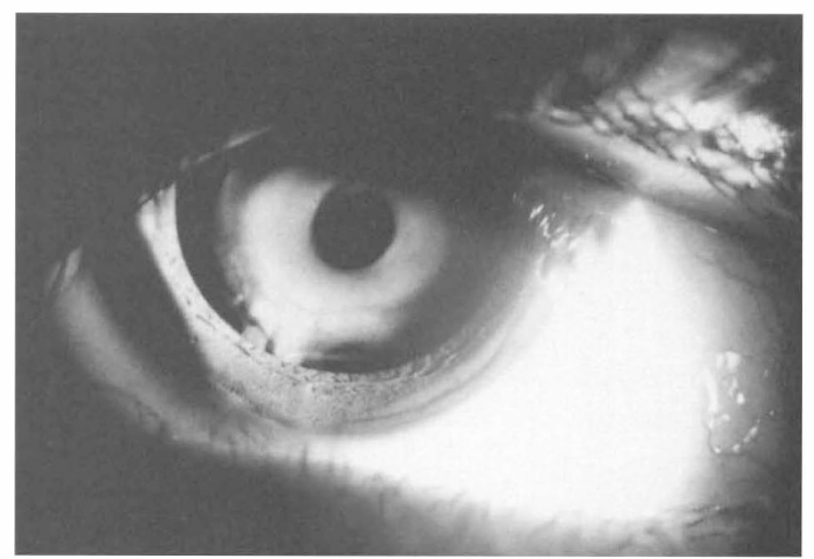

Fig. 15. A too-small capsulorhexis may contract to form a tiny round aperture. 
There is general consensus that IOLs are appropriate for most children with congenital cataract over 2 years of age. ${ }^{201,382-384}$ Younger patients can ethically be implanted if adequate attention can be paid to their optical correction and post-operative management.

To take account of the future growth of the eye the use of a lens of less than the power to give emmetropia may be used. ${ }^{385} \mathrm{~A}$ rule of thumb is to use a lens of 3 dioptres under-corrected for a 2-year-old rising proportionally to a lens to achieve emmetropia at 8 years, though there is no study yet to substantiate this or any other 'formula'. An over-correction with contact lenses or spectacles may be indicated in younger patients. The idea of implanting two lenses, one to be permanently in place in the capsular bag and one in the sulcus to be removed after the growth of the eye has taken place, is probably too invasive. Side effects and complications were frequent in earlier series, ${ }^{369,380}$ and are still important. Prolonged, meticulous and honest ${ }^{377}$ follow-up is the only way that we are going to find out how much early enthusiasm ${ }^{386}$ needs to be tempered with caution.

Posterior capsule opacification is common. ${ }^{264}$ There is little doubt that posterior capsule opacification is reduced by posterior capsulotomy or capsulorhexis with or without an anterior vitrectomy. ${ }^{258,265,268,329,377,387,388}$ It may occur even after a posterior capsulotomy, 370 probably by invasion of the anterior vitreous or hyaloid face by proliferating lens fibres or fibroblasts, and Metge ${ }^{389}$ found the incidence of opacification was $73 \%$ in those with an intact posterior capsule and $63 \%$ in those who had had a posterior capsulorhexis or anterior vitrectomy.

Uveitis shows itself as a red and photophobic eye, as an eye whose vision is unexpectedly poor due to cystoid macular oedema, and on slit-lamp examination there may be flare, cells in the anterior chamber and keratic precipitates $(\mathrm{KP})$ on the posterior surface of the cornea and both surfaces of the lens. Apple et al. ${ }^{390}$ noted several of the ways in which post-operative uveitis can occur: mechanical, immunological and complement activation, or the 'toxic lens syndrome', due to the leaching out of toxic chemicals from the lens. Phacotoxic and phacoanaphylactic reactions are more likely to occur as a reaction to the crystalline lens itself ${ }^{296,297}$ rather than the implant. Fibrinous uveitis is frequent in the early postoperative period ${ }^{391}$ and may result in posterior synechiae or secondary membranes; ${ }^{241,247,267,374}$ occasionally it may be severe and the result disastrous (Fig. 16). The membrane may require the use of tissue plasminogen activator, ${ }^{392}$ hirudin (experimentally) ${ }^{393}$ or YAG laser treatment. ${ }^{394}$ Most frequently it is prevented by the use of heparin ${ }^{395}$ at a concentration of $5 \mathrm{IU} / \mathrm{ml}$ of infusion fluid, and careful handling of the tissues, especially the iris. Unilateral ${ }^{250}$ and bilateral ${ }^{396}$ blinding uveitis have been described in patients who have had iris-fixated lenses.

Posterior synechiae are common, ${ }^{370,397}$ usually related to the post-operative fibrinous uveitis, but reduce with time.

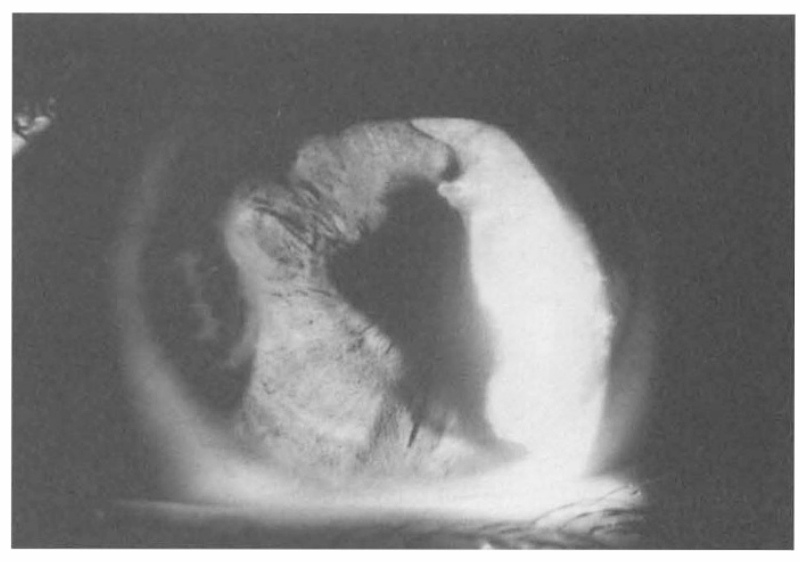

Fig. 16. Following a severe post-operative fibrinous uveitis, secondary membrane formation and glaucoma this pseudophakic eye became phthisical.

Lens displacement, dislocation and iris capture are not infrequent in sulcus-fixated lenses ${ }^{398}$ but are less frequent with newer posterior chamber lens techniques.

Haptic breakage has been reported in monkeys ${ }^{399,400}$ but is probably not significant in man, at least for the current follow-up periods.

In the experimental situation glaucoma can be frequent after neonatal implantation. ${ }^{401}$ Malignant glaucoma has been described, ${ }^{287}$ and glaucoma occurs after anterior chamber lens implantation, ${ }^{377}$ but is not likely to be more frequent after uncomplicated 'in-thebag' lens placement.

Corneal endothelial counts are reduced after the implantation of an IOL. Lenses implanted outside the posterior chamber are probably worst, ${ }^{253}$ whilst posterior chamber lenses may have little effect on the endothelium. ${ }^{402}$

Iris damage, sphincter damage or rupture, irregular pupils and iris atrophy were all common in early series. $^{369,377,380,390,403}$ They are largely avoided or reduced by: good pre-operative pupil dilatation, careful technique, avoiding iris touch, pre-operative nonsteroidal anti-inflammatory agents (orally or topically), maintaining pupil dilatation by $1: 10000$ adrenaline ( $2.5 \mathrm{ml}$ of a preservative-free solution in $250 \mathrm{ml}$ of infusion fluid) and the use of iris hooks if the pupil is undilatable. Iris prolapse $\mathrm{e}^{264}$ is uncommon now that a scleral tunnel is the most commonly used technique.

\section{Secondary intraocular lenses}

Secondary IOLs can be successfully implanted in children who have an adequate posterior capsule to support the lens. ${ }^{280,398,404}$ The site of the implant is less satisfactory than in primary implants because secondary IOLs are usually in the ciliary sulcus. It is possible to reconstruct the capsule to, in effect, place the lens 'in-thebag'. ${ }^{405}$ Sulcus ring or suture fixation ${ }^{280}$ may well not last the child's lifetime, and in adults secondary IOLs may relatively predispose the eye to later endophthalmitis. ${ }^{406}$ 
Table 3. Factors influencing visual prognosis in bilateral cataract

\begin{tabular}{ll}
\hline Factors giving a good prognosis & Factors giving a poor prognosis \\
\hline Late onset of the visual defect & Early onset of the visual defect \\
Early surgery, if surgery indicated & Late surgery, if the visual defect is of early onset \\
Early post-operative optical correction & Late post-operative optical correction \\
Non-dense opacity & Dense opacity \\
Lamellar or nuclear opacity & Large opacity or total cataract \\
Otherwise healthy eye & Other eye abnormalities, i.e. microphthalmos, PHPV, corneal anomalies \\
Small opacity & Operative or post-operative complications \\
Good compliance with amblyopia management & Pre-operative nystagmus \\
& Un-occluded squint \\
& Poor compliance with amblyopia management
\end{tabular}

\section{Amblyopia management in bilateral cataract}

The most important part of the management of the amblyopia in bilateral congenital cataract involves prompt surgery and accurate optical correction, but if these two factors only are relied on there will almost invariably be one eye that will be amblyopic. The acuity can be measured by Forced Choice Preferential Looking techniques (FPL), and the occlusion can be modulated according to the measured acuity. ${ }^{210}$

The Great Ormond Street Occlusion Protocol for Bilateral Cataracts is as follows:

1. $0-1.2$ octaves inter-ocular difference in visual acuity $\longrightarrow$ no occlusion

2. '1-2 octaves difference $\longrightarrow$ 1-2 h of occlusion of the preferred eye

3. More than 2 octaves difference $\longrightarrow 2-4$ h of occlusion of the preferred eye

4. If no improvement after stage $3 \longrightarrow$ Full-time occlusion, review every 1-2 weeks.

Older children who can cooperate with letter matching or other acuity measurements can be occluded in a similar manner; it must be remembered that single-letter acuity measurements may over-estimate the acuity. If the acuity cannot be measured, but the child has a squint, or there is objection to the covering of one eye more than the other, then occlusion of the preferred eye can be carried out empirically. If there is no squint there is a case for occluding alternate eyes for less than $1 \mathrm{~h}$ per day.

\section{Visual results in bilateral cataract}

Many of the earlier series ${ }^{20,21,30,272,407-409}$ that analysed the factors that led to good visual results noted that early surgery was associated with poor visual results - quite the opposite to the situation today. It seems likely that these results were caused by inadequate optical correction and occlusion.
As the experimental work on amblyopia was applied to the clinical management of congenital cataract. ${ }^{17,333,410}$ so the beneficial effects of early surgery on visual development became apparent. ${ }^{25,219,225,336,411,412}$ Age at surgery is not the only important factor (Table 3), and in one series ${ }^{26}$ was not a significant factor. Most series contain a number of biases, including the inclusion of various ages of onset of the visual defect, varying cataract morphology, different ages at operation and differing surgical techniques. It is not yet certain whether visual results differ with different types of optical correction. $^{381}$

It is in infants that the achievement of good visual results is most difficult. Lorenz in $1994^{22}$ summarised her own work and that of others; ${ }^{25,38,149,333} 50 \%$ of her own cases operated in the first year of life with total or axial cataracts achieved $20 / 50$ or better, and $70 \%$ achieved better than 20/100. Fifty per cent of the children with early surgery and optical correction had some binocular function. Hing et al. ${ }^{38}$ retrospectively looked at the medical records of 212 patients with all types of crystalline lens problems requiring surgery. They included 59 patients with simple congenital cataracts, of whom 26 had linear acuity measurements. Their results for those patients who had severe visual deprivation from birth are tabulated in Table 4. It is therefore important to realise, and to communicate to the parents, that in the early onset cases there is likely to be a visual defect even after optimal management.

Hing's ${ }^{38}$ infantile group, as expected, did better, with a mean visual acuity of $6 / 13$, and the juvenile group, with a mean age at surgery of 82 months, achieved 6/9. Most of the recent series ${ }^{329,387,398}$ that give visual results after IOL implantation show the very good visual results that are expected with most of the patients having lateronset visual deprivation.

Table 4. Bilateral cataracts with congenital-onset visual deprivation

\begin{tabular}{|c|c|c|c|c|}
\hline Age at surgery (months) & 1-2 & 3-4 & 5-6 & 7-12 \\
\hline Mean binocular VA & $0.32(6 / 18)$ & $0.18(6 / 33)$ & $0.23(6 / 26)$ & $0.25(6 / 24)$ \\
\hline No. of patients & 6 & 7 & 7 & 6 \\
\hline No. with VA of $6 / 24+$ & 5 & 2 & 4 & 3 \\
\hline Mean follow-up (months) & 48 & 67 & 63 & 57 \\
\hline
\end{tabular}




\section{Unilateral cataract and related disorders}

\section{Aetiology}

Unlike bacterial congenital cataract, unilateral cataracts are not usually associated with systemic disease. Many apparently unilateral cataracts may be bilateral but asymmetrical and slit-lamp examination is mandatory. Many cases are idiopathic but PHPV and posterior lenticonus are frequent. They may occur with congenital infections; rubella cataracts may be unilateral, without exceptional intraocular damage, but in varicella, cytomegalovirus or toxoplasmosis a cataract is usually secondary to extensive retinal disease. Microphthalmos is a frequent association.

\section{Amblyopia, and the visual results}

Published results of unilateral cataract treatment from the early part of this century were universally poor; ${ }^{17,18,20,21,29,103,215,272,408,413}$ 'surgery for unilateral congenital cataract is strongly advised against', ${ }^{103}$ 'surgery for unilaterals is not justified', ${ }^{20}$ 'everyone knows the uselessness of operating on unilateral congenital cataract'. ${ }^{272}$

As amblyopia research reached the ears of clinicians, the first attempts were made at management by early surgery, optical correction and occlusion, some with vision monitored by VEPs or FPL. ${ }^{17,34,217,414-416}$ Mostly these were not consistently successful, although promising. "The dictum of extreme conservatism in the management of monocular cataracts in children needs to be re-evaluated' ${ }^{417}$

Beller et al., in 1981, occluded both eyes of their early operated patients until the contact lens was fitted, then patched the fellow eye for $96 \mathrm{~h}$, then for a variable amount, depending on the results of VEP monitoring; 5 of their 8 patients achieved $6 / 9$ or better! It is most likely that it is the occlusion more than any other factor that determines the visual outcome. ${ }^{23,27,418}$

A number of studies $19,22,27,204,205,209-212,412,418-423$ strongly suggest that surgery before 2 months of postterm age, early and consistent optical correction, and early and full compliance with occlusion treatment are the keys to the achievement of good vision (say 6/9 acuity in the majority) in the monocularly aphakic eye.

There is some evidence that eyes which may appear to have PL visual acuities within the normal range in infancy and early childhood may fall below normal as time goes by. ${ }^{212,420,423}$ Not all recent visual results are in accord with the importance of early treatment in the attainment of good acuities; ${ }^{381}$ the poor results with early treatment may be due to compliance or optical problems.

The patients who have achieved high acuity levels had a wide variety of occlusion regimes, many monitored by FPL. At Great Ormond Street Hospital, since there is some evidence that excessive early occlusion may be associated with an increase in nystagmus and effects on the phakic eye, we now follow the regime of phakic eye occlusion: $1 \mathrm{~h}$ per day for each month of age until the baby is 6 months old; from 6 months old the vision continues to be monitored by FPL, and the amount of occlusion of the phakic eye is modulated, depending on the inter-ocular difference:

1. $0-1 / 2$ octave difference $\longrightarrow 50 \%$ of waking hours

2. $1-2$ octaves difference $\longrightarrow 75 \%$ of waking hours

3. $>2$ octaves difference $\longrightarrow 100 \%$ of waking hours (reviewed every 2 weeks)

\section{Pattern Reversal VEP}

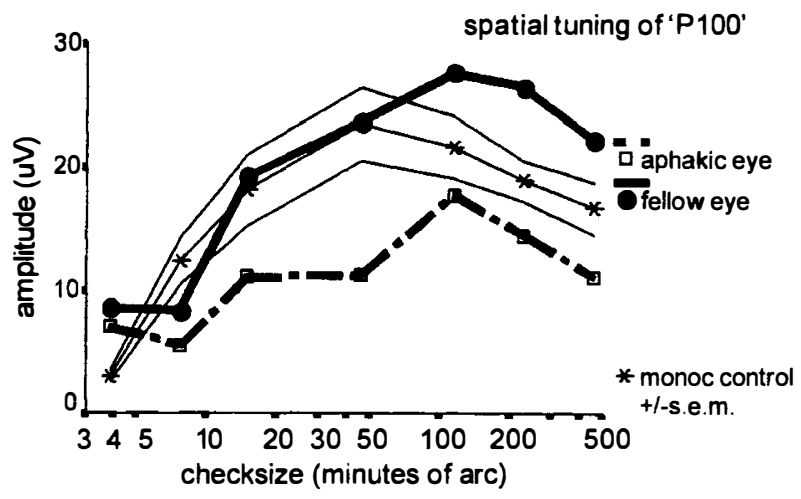

(a)

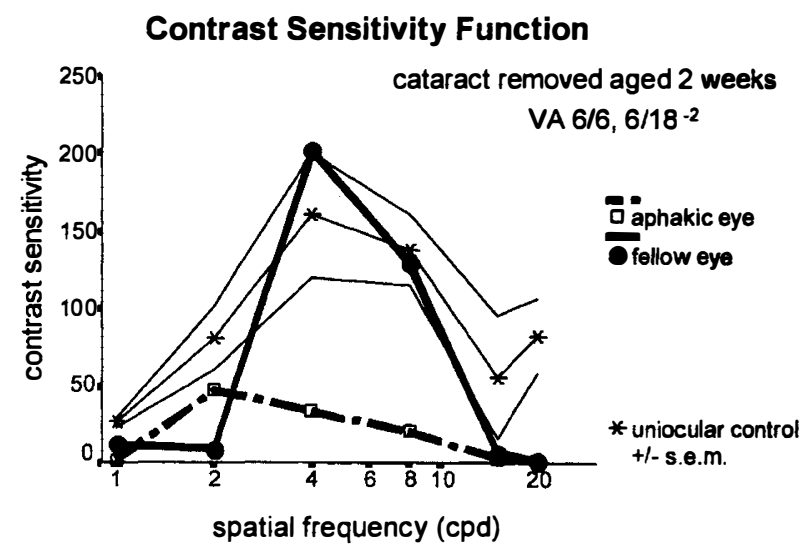

(b)

Fig. 17. Uniocular aphakia. (a) The amplitude of pattern reveral VEPs from aphakic and fellow eyes of a 6-year-old patient are plotted as a function of check-size. These data illustrate the best patient outcome of the ongoing study of Thompson et al.; ${ }^{208}$ the patient's unilateral congenital cataract was removed at 2 weeks old, and the fellow eye was patched for $50 \%$ of the waking day for the first 9 months of life. There is no detectable strabismus, monocular OKN is symmetrical, there is no nystagmus, but no stereoacuity was demonstrable. Pattern reversal VEPs were elicited to $80 \%$ contrast black and white checkerboard phase-reversing at $1.5 \mathrm{~Hz}, 3$ reversals per second. (b) Contrast sensitivity functions from the same patient as in (a) also demonstrate that the fellow eye approximates to the mean contrast sensitivity values of the uniocular control group data. The aphakic eye, however, demonstrate marked loss of sensitiviity at all but the lowest spatial frequencies in spite of a linear visual acuity of 6/18 part in this eye. Contrast sensitivity functions were measured to horizontal sine wave gratings presented in a Two Alternative Forced Choice (2AFC) paradigm. 


\section{Binocular vision after treatment for unilateral congenital cataract}

Untreated later-onset monocular traumatic cataracts may be associated with horror fusionis without amblyopia, but congenital, unilateral cataracts have traditionally had little ${ }^{424}$ or no binocular vision, even when the acuity in the affected eye is good. ${ }^{22,425}$ Some cases were demonstrated to have rudimentary binocular vision ${ }^{423,426,427}$ and a few had some stereopsis. ${ }^{428-430}$ One patient who had had a progressive occlusion regime achieved $20 / 25$ acuity and 50 seconds of arc stereoacuity confirmed by an independent ophthalmologist. ${ }^{431}$

\section{Practical management}

Fully informed consent by the parents is a vital prerequisite to proceeding with treatment. It is an essential fact that treatment is not mandatory. The parents must be given a clear account of all the alternatives, compatible with their understanding of the matter, and when possible they should be the ones to make the decision. It is vital that the parents are appraised of the fact that the surgery is a small, but important, part of the treatment of amblyopia; good visual results depend on the prolonged use of one or other form of optical correction, but mostly on the maintenance of a regime of occlusion, ${ }^{23,27}$ for many years.

Unilateral congenital cataract is not a socially significant disease: it must be a coincidence of considerable rarity if a person who has had such a cataract successfully treated (creating a 'spare eye') blinds the phakic eye. By reducing things to the absurd, there are many circumstances where treatment is actually contraindicated. More obvious ones include first the child living in circumstances where treatment is economically unjustifiable: who would treat a unilateral congenital cataract in many a developing country when there may be many times more who are blind from bilateral cataract? Second, there are the cases where the parents are unable to carry out the all-important postoperative care (one must remember that in many 'advanced' countries there are areas where the adult illiteracy rate is substantial: these disadvantaged people are probably the least likely to go through with the rigours of treatment). Failure to carry out either occlusion or optical correction will inevitably give poor visual results. ${ }^{23,27}$ Third, treatment is inappropriate where life expectancy is reduced. Last, there are the cases where the prognosis is very poor; in only exceptional circumstances is a good visual result obtained with treatment that starts after the first months of life.

The parents need to be appraised of the fact that there is a significant chance that the eye may be damaged by the surgery itself, by glaucoma, retinal detachment, or by the wearing of a contact-lens (see above). Even the phakic eye may be blinded. ${ }^{396}$
If taking days off work, long distance travel, repeated clinic visits, ${ }^{420}$ fees and all other disbursements are taken into account, the costs and the disturbance to the daily lives of patients and their parents are very substantial.

Although there are now many studies that demonstrate that good visual results can be obtained in a substantial proportion of cases, these results have mostly been obtained by patients at renowned referral centres, with the excellent treatment and parental motivation that that implies. There are a few dozen of these cases in the world literature: the numbers that have not had this happy outcome is not known, but it must be many times the number of good ones. Even in major referral centres, the ability to achieve a good functional result (i.e. driving vision) is unlikely to be more than $50 \%$ of patients presenting with unilateral congenital cataract, before exclusions are made. ${ }^{25}$ The achievement of good binocular vision is so rare as to be noteworthy, and strabismus is the rule in congenital cataract. ${ }^{432}$

There is a possibility that the vision of the phakic eye may be altered by the treatment of the cataractous eye. This may include defects of acuity ${ }^{208,433}$ (Fig. 17) or contrast sensitivity; ${ }^{433}$ rarely patients may fix with the phakic eye. These complications are subtle and not universal. ${ }^{319,423}$

Manifest latent nystagmus (MLN) is frequent after unilateral cataract treatment, and it may also occur in untreated cases. Because there is often a nystagmus null position in the adducted position of the phakic eye, there is often an abnormal head posture with the face turned towards the phakic eye. The nystagmus may be less frequent when the monocular deprivation is profound enough to give marked abnormalities in the visually evoked cortical potentials. In these profoundly deprived cases, the persistent optokinetic nystagmus (OKN) asymmetry that is seen in cases where the deprivation is less profound (such as treated unilateral cataract) is not observed, suggesting that it is the lack of unequal input and interocular competition that allows normal OKN development. ${ }^{434}$ It has been suggested, to the contrary, that early surgery for monocular congenital cataract (which reduces the deprivation and increases interocular competition) may lessen the nystagmus by allowing a more equal sensory input. ${ }^{435}$

Although the psychosocial consequences may be a significant problem, ${ }^{337}$ children who do have behavioural abnormalities that interfere with or even stop treatment may also have other family, medical or environmental disturbances, and these problems are not inevitable ${ }^{436}$ or even frequent. An unpublished study from Great Ormond Street Hospital failed to demonstrate any significant problems with bonding and attachment.

There are, of course, important reasons why treatment may be in the best interests of the child; a poor cosmetic appearance because of a white pupil, especially in a microphthalmic eye, is a cosmetic blemish that is unsightly and difficult to treat with a cosmetic shell or contact lens in a young child. The achievement of good vision (say, that compatible with passing the driving test) is regularly achieved. This has the benefit that a 'spare' 
eye is created, in case of accident or disease; an amblyopic's fellow eye may be more at risk than the fellow eye of a normal. ${ }^{437}$ In a small, but increasing number of cases some degree of binocular vision is achieved, ${ }^{423,431}$ which has functional benefits of its own but also reduces the normally very high incidence of strabismus and may reduce the incidence and severity of nystagmus. ${ }^{435}$ There is also a case to be made that the 'sound' eye may not always be as sound as it appears at presentation, ${ }^{438}$ which may increase the need to treat the cataractous eye.

Most parents are usually keen for their child to have the cataract removed and to undergo the optical treatment and amblyopia management.

\section{Optical correction in uniocular cataract}

Aniseikonia makes the use of spectacles the last resort as a primary correction, but they can be useful as a way of fine adjustment to an IOL or for the near/distance correction of bifocals or as a part of a contact lens-spectacle combination to counter aniseikonia. ${ }^{350}$ In the latter technique a combination of a high-plus contact lens is used with a minus spectacle lens; the method has not been widely used because the amount of aniseikonia with contact lens correction is not enough to interfere with the development of binocular vision, where this is possible. Contact lenses are the standard at the moment, because of their safety and ability to be changed. IOLs have many advantages, and are the treatment of choice in children over 2 years old; ${ }^{384}$ they are being considered for infants.

\section{Postscript}

'In cases of congenital cataract ought the operation to be delayed till the patient has attained an age sufficient to enable him to understand the importance of an attempt to restore sight or ought it to be practised during infancy? The answer decidedly is, operate in infancy, and if possible before teething commences' (William Mackenzie, $1840^{179}$ ).

I owe a debt of gratitude to many people for help with this lecture: Miss Carole Reeves, Professor Tony Bron and Mr Adrian Hill of Oxford Eye Hospital, Mr Gordon Catford, Mr Ray Lunnon and Mr Nicholas Baldwin of Great Ormond Street Hospital Archives who all helped with the historical parts of the paper. I received great support from the Ophthalmology Department at Great Ormond Street, especially Miss Isabelle Russell-Eggitt, Dr Tony Kriss, Dr Chris Harris, Mr Peter West, Dr Fatima Shawkat, Dr Dorothy Thompson, Mrs Christine Timms, Miss Deborah Rush and Mrs Blanche Stiff. Dr Jugnoo Rahi advised on epidemiological matters, Miss Lynne Speedwell and Mrs Lucy Forrest on contact lenses, and most of the illustrations were taken and prepared by our department of medical illustration, led by $\mathrm{Mr}$ Jeremy Naylor. Mr Alex Ionides helped with research into the gene loci. Miss Angela Tank has shown unswerving energy and resourcefulness in helping me with this lecture, whilst remaining calm and running the service aspects of Great Ormond Street Eye Department.

\section{References}

1. Catford GV. Our founder, Robert Doyne. Trans Ophthalmol Soc UK 1976;96:285-9.

2. Lascaratos J, Marketos S. An historical outline of Greek ophthalmology from the Hellenistic period up to the establishment of the first universities. Doc Ophthalmol 1988;68:157-69.

3. Pott P. The chirurgical works of Percival Pott. Paternoster Row, London: Haws, W Clark and R Collins, 1775.

4. Saunders John Cunningham. A treatise on some practical points relating to the diseases of the eye. London: Longman, Hurst, Rees, Orme and Brown, 1816.

5. Ziegler SL. Complete discission of the lens by the V-shaped method. J Am Med Assoc 1921;77:1100-2.

6. Gibson B. Practical observations on the formation of an artificial pupil, in several deranged states of the eye. London: Cadell and Davies in the Strand, 1811.

7. Scheie HG, Ewing MQ. Aspiration of soft cataracts. In: Hiles DA, editor. Infantile cataract surgery. Boston: Little, Brown, 1977:51-8.

8. Teale TP. On extraction of soft cataract by suction. Lancet 1984;ii:348.

9. Scheie HG. Aspiration of congenital or soft cataracts: a new technique. Am J Ophthalmol 1960;50:1048-56.

10. Rice NSC. Lens aspiration: a decade in retrospect. Trans Ophthalmol Soc UK 1977;97:48-51.

11. Streiff EB. L'éxtraction intracapsulaire chez les petits enfants et les enfants à l'alphachymotrypsine. Arch Soc Am Ophthalmol Optom 1956;2:305-7.

12. Dolcet-Buxeres L. Juvenile and congenital cataracts: a new surgical procedure. J Pediatr Ophthalmol 1966;3:24-5.

13. Collins ET. Developmental deformities of the crystalline lens. Ophthalmoscope 1908;6:577-583, 663.

14. Alexander GF. The immediate removal of congenital cataracts. Trans Ophthalmol Soc UK 1928;48:94-107.

15. Nutt $A B$. The surgical treatment of congenital cataract. Trans Ophthalmol Soc UK 1957;77:39-57.

16. Juler F. Amblyopia from disuse. Visual acuity after traumatic cataract in children. Trans Ophthalmol Soc UK 1921;41:129-39.

17. Von Noorden GK, Ryan SJ, Maumenee AE. Management of congenital cataracts. Trans Am Acad Ophthalmol Otol 1969;74:352-9.

18. Merin S, Crawford JS. Assessment of incomplete congenital cataract. Can J Ophthalmol 1972;7:56-62.

19. Beller RB, Hoyt CS, Marg E, Odom JV. Good visual function after neonatal surgery for congenital monocular cataract. Am J Ophthalmol 1981;91:559-65.

20. Deweese MW. A survey of the surgical treatment of congenital cataracts. Am J Ophthalmol 1962;53:853-7.

21. Prudhommeaux $P$. Le résultat óbtenu après opération pour cataracte congénitale. Bull Soc Ophtalmol Fr 1962;62:383-430.

22. Lorenz B, Wörle J, Friedl N, Boergen K-P. Monocular and binocular functional results in cases of contact lens corrected infant aphakia. In: Cotlier E, Lambert S, Taylor D, editors. Congenital cataracts. Austin, Texas: RG Landes, 1994:151-63.

23. Elsas FJ. Visual acuity in monocular pediatric aphakia: does epikeratophakia facilitate occlusion therapy in children tolerant of contact lens or spectacle wear? J Pediatr Ophthalmol Strabismus 1990;27:304-9.

24. Hiles DA. Visual results following infantile cataract surgery. In: Hiles D, editor. Infantile cataract surgery. Boston: Little, Brown, 1977:265-82.

25. Gelbart SS, Hoyt CS, Jastrebski G, Marg E. Long term visual results in bilateral congenital cataracts. Am J Ophthalmol 1982;93:615-21.

26. Bradford G, Keech R, Scott W. Factors affecting visual outcome after surgery for bilateral congenital cataracts. Am J Ophthalmol 1994;117:58-64. 
27. Moore B. The cause of treatment failure in patients with unilateral congenital cataracts. In: Cotlier E, Lambert S, Taylor D, editors. Congenital cataracts. Austin, Texas: RG Landes, 1994:143-8.

28. Taylor DSI, Vaegan, Morris JA, Rodgers JE, Warland J. Amblyopia in bilateral infantile and juvenile cataract: relationship to timing of treatment. Trans Ophthalmol Soc UK 1979;99:170-5

29. Bouzas A. Les résultats postopératoires de la cataracte congénitale. Arch d'Ophtalmol 1955;15:164-73.

30. Broendstrup P. Operative results obtained in bilateral infantile cataract. Acta Ophthalmol (Copenh) 1945;23:175-94.

31. Yamamoto M, Bun JE, Okuda J. Visual functions after traumatic cataract in children. In: Henkind $P$, editor. Acta XXIV International Congress of Ophthalmology. Philadelphia: JB Lippincott, 1983.

32. Vaegan, Taylor DSI. Critical period for deprivation amblyopia in children. Trans Ophthalmol Soc UK 1979;99:432-9.

33. Birch EE, Stager DR. The critical period for surgical treatment of dense congenital unilateral cataract. Invest Ophthalmol Vis Sci 1996;37:1532-8.

34. Von Noorden GK. Recent advances in amblyopia: the mechanisms of amblyopia, their relation to management of congenital cataract. Ophthalmic Digest 1976;3946 (July). B Boyd.

35. Rice NSC, Taylor DSI. Congenital cataract: a cause of preventable blindness. BMJ 1982;285:581-2.

36. Taylor DSI, Rice NSC. Congenital cataract, a cause of preventable blindness. Arch Dis Child 1982;57:165-7.

37. Taylor DSI. Cataracts in children. J R Soc Med 1985;78:1-3.

38. Hing S, Speedwell L, Taylor DSI. Lens surgery in infancy and childhood. Br J Ophthalmol 1990;74:73-8.

39. Birth Defects Monitoring Program (BDMP). Birth Defects Monitoring Program (BDMP)/Commission on Professional and Hospital Activities (CPHA). Surveillance data 1988-1991. Teratology 1993;48:658-75.

40. Metropolitan Atlanta Congenital Defects Program. Metropolitan Atlanta Congenital Defects Program (MACDP) Surveillance Data 1988-1991. Teratology 1993;48:695-709.

41. Stoll C, Alembik Y, Dott B, Roth MP. Epidemiology of congenital eye malformations in 131760 consecutive births. Ophthalmic Paediatr Genet 1992;13:179-86.

42. Köhler L, Stigmar G. Vision screening of four-year-old children. Acta Pediatr Scand 1973;62:17-27.

43. Stewart-Brown SL, Haslum MN. Partial sight and blindness in children of the 1970 birth cohort at 10 years of age. J Epidemiol Community Health 1988;42:17-23.

44. Stayte M, Reeves B, Wortham C. Ocular and vision defects in preschool children. Br J Ophthalmol 1993;77:228-32.

45. Stayte M, Johnson A, Wortham C. Ocular and visual defects in a geographically defined population of 2-year-old children. Br J Ophthalmol 1990;74:465-8.

46. Stambolian D. Galactose and cataract. Surv Ophthalmol 1988;32:333-49.

47. Endres W, Shin YS. Cataract and metabolic disease. J Inherit Metab Dis 1990;13:509-16.

48. Sardharwalla IB, Wraith JE, Bridge C, Fowler B, Roberts SA. A patient with severe type of epimerase deficiency galactosaemia. J Inherit Metab Dis 1988;11 (Suppl 2):249-51.

49. Brivet M, Abadie V, Soni T, Cheron G, Dufier JL. Inexplicable infantile cataracts and partial maternal galactose disorder. Arch Dis Child 1986;61:445-9.

50. Stevens RE, Datiles MB, Srivastava SK, Ansari NH, Maumenee AE, Stark W. Idiopathic presenile cataract formation and galactosaemia. Br J Ophthalmol 1989;73:48-51.
51. Harley JD, Mutton P, Irvine S, Gupta JD. Maternal enzymes of galactose metabolism and the 'inexplicable' infantile cataract. Lancet 1974;ii:259-71.

52. Vetter V, Shin YS. Lens sorbitol dehydrogenase deficiency in a patient with congenital cataract. Eur J Paediatr 1995;154:389-91.

53. Kjellman B, Gamstrop I, Brun A, Ockerman P-A, Palmgren B. Mannosidosis: a clinical and histopathologic study. J Pediatr 1969;75:366-73.

54. Gabilan JC, Chaussain JL. L'association hypoglycemie idiopathique et cataracte chez l'enfant. Arch Franc Ped 1969;26:633-40.

55. Wilson WA. Ocular findings in ketotic hypoglycemia. Trans Am Ophthalmol Soc 1969;67:355.

56. Merin S, Crawford JS. Hypoglycemia and infantile cataract. Arch Ophthalmol 1971;86:495-8.

57. McKinna AJ. Neonatal hypoglycemia: some ophthalmic observations. Can J Ophthalmol 1966;1:58-9.

58. Hochman HI, Mejlszenkier JD. Cataracts and pseudotumour cerebri in an infant with vitamin D deficiency rickets. J Pediatr 1977;90:252-4.

59. Kohn BA. The differential diagnosis of cataracts in infancy and childhood. Am J Dis Child 1976;130:184-92.

60. Merin S, Crawford JS. The etiology of congenital cataracts: a survey of 386 cases. Can J Ophthalmol 1971;6:178-82.

61. Duncan G, Williams MR, Riach RA. Calcium, cell signalling and cataract. Prog Ret Eye Res 1994;13:623-52.

62. Cotlier E, Rice P. Cataracts in the Smith-Lemli-Opitz syndrome. Am J Ophthalmol 1971;72:955-9.

63. Finlay SC, Finlay WH, Monsky DM. Cataracts in a girl with features of Smith-Lemli-Opitz syndrome. J Pediatr 1969;75:706-7.

64. Cenedella RJ. Cholesterol and cataracts. Surv Ophthalmol 1996;40:320-37.

65. Goss-Sampson M, Russell-Eggitt I, Lloyd C. Oxidative damage and cataract formation. In: Cotlier E, Lambert S, Taylor D, editors. Congenital cataracts. Austin, Texas: RG Landes, 1977:49-53.

66. Lloyd IC, Goss-Sampson M, Jeffrey BG, Kriss A, RussellEggett I, Taylor DSI. Neonatal cataract: aetiology, pathogenesis and management. Eye 1992;6:184-96.

67. Varma SD, Chand D, Sharma YR, Kuck JF, Richards RD. Oxidative stress on lens and cataract formation: role of light and oxygen. Curr Eye Res 1984;3:35-57.

68. Augusteyn RC. Mechanisms of cataract formation in the human lens. London: Academic Press, 1981.

69. Bunce GE, Hess $\mathrm{JL}$. Lenticular opacities in young rats as a consequence of maternal diets low in tryptophan and/or vitamin E. J Nutrit 1976;106:222-9.

70. Bras A, Monteiro C, Rueff J. Oxidative stress in trisomy 21: a possible role in cataractogenesis. Ophthalmic Paediatr Genet 1989;10:271-7.

71. Nordmann J, Klethi J, Gerhard J-P. Observations concernant les cataracts congénitales et post-natales précoces. Bull Soc Franc Ophtalmol 1970;70:168-70.

72. Alden ER, Kalina RE, Hodson WA. Transient cataracts in low-birth-weight infants. J Pediatr 1973;82:314-8.

73. McCormick AQ. Transient cataracts in premature infants: a new clinical entity. Can J Ophthalmol 1968;3:202-6.

74. Yanoff M, Fine BS, Schaffer DB. Histopathology of transient neonatal lens vacuoles. Am J Ophthalmol 1973;76:363-70.

75. Capone A, Drack AV. Transient lens changes after diode laser retinal photoablation for retinopathy of prematurity [letter]. Am J Ophthalmol 1994;118:533-5.

76. Gold RS. Cataracts associated with treatment for retinopathy of prematurity. J Pediatr Ophthalmol Strabismus 1997;34:123-4.

77. Cartier M, Tsui L, Ball SP, Lubsen NH. Crystallin genes and cataract. In: Wright AF, Jay B, editors. Molecular genetics of inherited eye disorders. Switzerland: Harwood Academic, 1994:413-44. 
78. McAvory JW. Developmental biology of the lens. In: Duncan G, editor. Mechanisms of cataract formation in the human lens. London: Academic Press, 1981:7-46.

79. Brakenhoff RH, Henskens HAM, van Rossum MWPC, Lubsen NH, Schoenemakers JGG. Activation of the gamma E-crystallin pseudogene in human hereditary Coppock-like cataract. Hum Mol Genet 1994;3:270-83.

80. Sparkes RS, Mohandas T, Heinzmann C, Gorin MB, Horwitz J, Law $M$, et al. The gene for the major intrinsic protein (MIP) of the ocular lens is assigned to human chromosome 12cen-q14. Invest Ophthalmol Vis Sci 1986;27:1351-4.

81. Barrett DJ, Sparkes RS, Gorin MB, Bhat SP, Spence MA, Marazita ML, et al. Genetic linkage analysis of autosomal dominant congenital cataracts with lens-specific DNA probes and polymorphic phenotypic markers. Ophthalmology 1988;95:538-44.

82. Bateman JB, Spence MA, Marazita ML, Sparkes RS. Genetic linkage analysis of autosomal dominant congenital cataracts. Am J Ophthalmol 1986;101:218-25.

83. Conneally PM, Wilson AF, Merritt AD, Helveston EM, Palmer CG, Wang LY. Confirmation of genetic heterogeneity in autosomal dominant forms of congenital cataracts from linkage studies. Cytogenet Cell Genet 1978;22:295-7.

84. Lund AM, Eiberg H, Rosenberg T, Warburg M. Autosomal dominant congenital cataract: linkage relations; clinical and genetic heterogeneity. Clin Genet 1992;41:65-9.

85. Ionides A, Berry V, Mackay D, Bhattacharya S, Shiels A, Moore A. Clinical and genetic heterogeneity in autosomal dominant cataract. Arch Ophthalmol 1998; in press.

86. Stabile M, Amoriello A, Capobianco S, Cavaliere ML, Conte $\mathrm{N}$, De Rosa C, et al. Study of a form of pulverulent cataract in a large kindred. J Med Genet 1983;20:419-21.

87. Renwick SH, Lawler SD. Probable linkage between a congenital cataract locus and Duffy blood group locus. Ann Hum Genet 1963;27:67-84.

88. Eiberg H, Lund AM, Warburg M, Rosenberg T. Assignment of congenital cataract Volkmann type (CCV) to chromosome 1p36. Hum Genet 1995;96:33--8.

89. Lubsen NH, Renwick JH, Tsui L-C, Breitman ML, Schoenmakers JGG. A locus for a human hereditary cataract is closely linked to the gamma-cystallin gene family. Proc Natl Acad Sci USA 1987;84:489-92.

90. Rogaev EI, Rogaeva EA, Korovaitseva GI, Farrer LA, Petrin AN, Keryanov SA, et al. Linkage of polymorphic congenital cataract to the gamma-crystallin gene locus on human chromosome 2q33-35. Hum Mol Genet 1996;5:699-703.

91. Mackay DS, Ionides A, Berry V, Moore A, Battacharya S, Shiels A. A new locus for dominant 'zonular pulverulent' cataract on chromosome 13. Am J Hum Genet 1997;60:1474-8.

92. Marner E, Rosenberg T, Eiberg H. Autosomal dominant congenital cataract: morphology and genetic mapping. Acta Ophthalmol (Copenh) 1989;67:151-8.

93. Berry V, Ionides ACW, Moore AT, Bhattacharya SS, Shiels A. A locus for autosomal dominant anterior polar cataract on chromosome 17p. Hum Mol Genet 1996;5:415-9.

94. Padma T, Ayyagari R, Murty JS, Basti S, Fletcher T, Rao GN, et al. Autosomal dominant zonular-cataract with sutural opacities localised to chromosome 17q11-12. Am J Hum Genet 1995;57:840-5.

95. Armitage M, Kivlin J, Ferell R. A progressive early onset cataract gene maps to human chromosome 17q24. Nature Genet 1995;9:37-40.

96. Kramer P, Yount J, Mitchell T, LaMorticella D, CarreroValenzuela $\mathrm{R}$, Louvrien $\mathrm{E}$, et al. A second gene for cerulean cataracts maps to the beta-crystallin region on chromosome 22. Genomics 1996;35:39-42.
97. Lewis RA, Nussbaum RL, Stambolian D. Mapping X-linked ophthalmic diseases. IV. Provisional assignment of the locus for X-linked congenital cataracts and microcornea to Xp22.2-22.3. Ophthalmology 1990;97:110-20.

98. Zhu D, Alcorn DM, Antonarakis SE, Levin LS, Huang PC, Mitchell TN, et al. Assignment of the Nance-Horan syndrome to the distal short arm of the $\mathrm{X}$ chromosome. Hum Genet 1990;86:54-8.

99. Moross T, Vaithilingam SS, Styles S, Gardner HA. Autosomal dominant anterior polar cataracts with a familial 2; 14 translocation. J Med Genet 1984;21:52-3.

100. Yokoyama Y, Narahara K, Tsuji K, Ninomiya S, Seino Y. Autosomal dominant congenital cataract and microphthalmia associated with a familial $t(2 ; 16)$ translocation. Hum Genet 1992;90:177-8.

101. Reese PD, Tuck-Muller CM, Maumenee IH. Autosomal dominant congenital cataract associated with chromosomal translocation. Arch Ophthalmol 1987;105:1382-4.

102. Rubin SE, Nelson LB, Pletcher BA. Anterior polar cataract in two sisters with an unbalanced 3;18 chromosomal translocation. Am J Ophthalmol 1994;117:512-5.

103. Costenbader FD, Albert DG. Conservatism in the management of congenital cataracts. Arch Ophthalmol 1957;58:426-30.

104. Parks MM, Johnson DA, Reed GW. Long-term visual results and complications in children with aphakia: a function of cataract type. Ophthalmology 1993;100:826-41.

105. Crawford JS. Conservative management of cataracts. In: Hiles DA, editor. Infantile cataract surgery. Boston: Little, Brown, 1977:31-5.

106. Collier M. Nouvel exemple de variabilité des types de cataracte congénitale dans une même famille. Bull Soc Ophtalmol Fr 1968;68:910-1.

107. Scott MH, Hejtmancik JF, Wozencraft LA, Reuter LM, Parks MM, Kaiser Kupfer MI. Autosomal dominant congenital cataract: interocular phenotypic variability. Ophthalmology 1994;101:866-71.

108. Wegener JK, Sogaard H. Persistent hyperplastic primary vitreous with resorportion of the lens. Acta Ophthalmol (Copenh) 1968;46:171-5.

109. Boger WP, Peterson RA, Robb RM. Spontaneous absorption of the lens in the congenital rubella syndrome. Arch Ophthalmol 1981;99:433-4.

110. Smith G, Shun-Shin A, Bron A. Spontaneous reabsorption of rubella cataract. Br J Ophthalmol 1990;74:564-6.

111. Ehrlich LH. Spontaneous absorption of congenital cataract following maternal rubella. Arch Ophthalmol 1948;39:205-9.

112. Falls HF, Schull WJ. Hallermann-Streiff syndrome: a dyscephaly with congenital cataracts and hypotrichosis. Arch Ophthalmol 1960;63:419-20.

113. Soriano JM, Funk J. Bilateral spontaneous reabsorption of the lens in a case of Hallermann-Streiff syndrome. Klin Monatsbl Augenheilkd 1991;200:195-8.

114. Yamamoto Y, Hayaska S, Setogawa S. Family with aniridia, microcornea and spontaneously reabsorbed cataract. Arch Ophthalmol Strabismus 1988;106:502-5.

115. Ginsberg J, Bore KE, Fogelson MH. Pathological features of the eye in the oculocerebrorenal (Lowe) syndrome. J Pediatr Ophthalmol Strabismus 1981;18:16-24.

116. Tripathi RC, Cibis GW, Tripathi BJ. Pathogenesis of cataracts in patients with Lowe's syndrome. Ophthalmolology 1986;93:1046-51.

117. Rogers NK, Strachan IM. Pierre Robin anomalad, maculopathy and autolytic cataract. J Pediatr Ophthalmol Strabismus 1995;32:391-2.

118. Stevens PR. Anterior lenticonus and the Waardenburg syndrome. Br J Ophthalmol 1970;54:621-3.

119. Gailloud C, Streiff EB. Cataracte en bouée de sauvetage. Ophthalmologica 1972;165:212-8. 
120. Collins ET, Mayou MS. Pathology and bacteriology of the eye. 2nd ed. London: Heinemann, 1925.

121. Bartholomew RS. Sector shaped membranous cataract. J Pediatr Ophthalmol 1977;14:109-11.

122. Bouzas A. Anterior polar congenital cataract and corneal astigmatism. J Pediatr Ophthalmol Strabismus 1992;29:210-2.

123. Jaafar MS, Robb RM. Congenital anterior polar cataract: a review of 63 cases. Ophthalmology 1984;91:249-54.

124. Nelson LB, Calhoun JH, Simon J, Harley R. Progression of congenital anterior polar cataracts in childhood. Arch Ophthalmol 1985;103:1842-3.

125. Dohlman $\mathrm{CH}$. Familial cornea guttata in association with anterior polar cataracts. Acta Ophthalmol 1951;29:445-51.

126. Traboulsi EI, Weinberg RJ. Familial congenital cornea guttata with anterior polar cataracts [see comments]. Am J Ophthalmol 1989;108:123-5.

127. Thomas R, Gopal KS, George JA. Anterior dislocation of the pyramidal part of a congenital cataract. Ind J Ophthalmol 1985;33:51-2.

128. Brown N, Ellis P. Anterior polar pyramidal cataract presenting as an anterior chamber foreign body. $\mathrm{Br} \mathrm{J}$ Ophthalmol 1972;56:57-9.

129. Govan JA. Ocular manifestations of Alport's syndrome: a hereditary disorder of basement membrane. $\mathrm{Br} \mathrm{J}$ Ophthalmol 1983;67:493-503.

130. Jacobs M, Jeffrey B, Kriss A, Taylor D, Sa G, Barratt TM. Ophthalmologic assessment of young patients with Alport syndrome. Ophthalmology 1992;99:1039-44.

131. Arnott EJ, Crawfurd MD'A, Toghill PJ. Anterior lenticonus and Alport's syndrome. Br J Ophthalmol 1966;50:390.

132. Siedenberg K, Ludwig H. A newborn with posterior lenticonus [letter]. Am J Ophthalmol 1993;115:543-4.

133. Mohney BG, Parks MM. Acquired posterior lentiglobus. Am J Ophthalmol 1995;120:123-4.

134. Cheng KP, Hiles DA, Biglan AW, Pettapiece MC. Management of posterior lenticonus. J Pediatr Ophthalmol Strabismus 1991;28:143-9.

135. Crouch ER Jr, Parks MM. Management of posterior lenticonus complicated by unilateral cataract. Am J Ophthalmol 1978;85:503-8.

136. Wright KW, Christensen LE, Noguchi BA. Results of late surgery for presumed congenital cataracts. Am J Ophthalmol 1992;114:409-15.

137. Mann I. Developmental abnormalities of the eye. 2nd ed. London: British Medical Association, 1957.

138. Khalil M, Saheb N. Posterior lenticonus. Ophthalmology 1984;91:1429-30.

139. Tyson HH. Lenticonus posterior. Arch Ophthalmol 1928;53:38-50.

140. Vogt A. Über Lenticonus axialis und periphericus posterior. Klin Monatsbl Augenheilkd 1926;77:709-10.

141. Von Hess C. Über excentrische Bildung des Linsenkernes und die Histologie des Lenticonus posterior. Dtsch Ophthalmol Ges 1986;301:301.

142. Marsh EJ. Slit lamp study of posterior lenticonus. Arch Ophthalmol 1927;56:128-36.

143. Kilty LA, Hiles DA. Unilateral posterior lenticonus with persistent hyaloid artery remnant. Am J Ophthalmol 1993;116:104-6.

144. Butler TH. Lenticonus posterior: report of six cases. Arch Ophthalmol 1930;3:425-36.

145. Gibbs ML, Jacobs M, Wilkie AOM, Taylor DSI. Posterior lenticonus: clinical patterns and genetics. J Pediatr Ophthalmol Strabismus 1993;30:171-5.

146. Vivian AJ, Lloyd IC, Russell-Eggitt I, Taylor DSI. Familial posterior lenticonus. Eye 1995;9:119-23.

147. Bliek J, Traboulsi E, Maumenee IH. Familial posterior lenticonus and microcornea [letter]. Arch Ophthalmol 1992;110:1208-10.
148. Jain IS, Pillai P, Gangwar DN, Dhir SP, Kaul VK. Congenital cataract: etiology and morphology. J Pediatr Ophthalmol Strabismus 1983;20:238-42.

149. Parks MM. Visual results in aphakic children. Am J Ophthalmol 1982;94:441-9.

150. Freeman RS, Rovick LP. Cloudy lenses and issues: a pedigree of unoperated congenital cataracts. J Pediatr Ophthalmol Strabismus 1994;31:318-22.

151. Gitzelmann R. Hereditary galactokinase deficiency, a newly recognised cause of juvenile cataracts. Pediatr Res 1967;1:14-23.

152. Vogt A. Die Vorder axiale Embryonalkataract der menslichen Linse. Z Augenheilkd 1919;41:125-37.

153. DeJong PTVM, Bleeker-Wagemakers EM, Vrensen GFJM, Broekhuyse RE, Peerboom-Wynia JDR, Delleman JW. Crystalline cataract and uncombable hair. Ophthalmology 1990;97:1181-7.

154. Rennie AGR. The Whalsay cataract. Trans Ophthalmol Soc UK 1983;103:530-1.

155. Nettleship E, Ogilvie FM. A peculiar form of congenital cataract. Trans Ophthalmol Soc UK 1906;26:191-207.

156. Adams PH. Doyne's discoid cataract. Br J Ophthalmol 1942;26:152-3.

157. Rosen E. Coppock cataract and cataracta pulverulenta centralis. Br J Ophthalmol 1945;29:641-4.

158. Beigi B, O'Keefe M, Bowell R, Naughten E, Badawi N, Lanigan $B$. Ophthalmic findings in classical galactosaemia: prospective study. Br J Ophthalmol 1993;7:162-4.

159. Vogt A. Die Spezifität auder borener und erworbener starformer für die einzelnen Linzenzouene. Graefes Arch Ophthalmol 1922;108:219-28.

160. Pires da Cunha R, De Castro Moreira JB. Ocular findings in Down's syndrome. Am J Ophthalmol 1996;122:236-44.

161. Berk AT, Saatci AO, Ercal MD, Tunc M, Ergin M. Ocular findings in 55 patients with Down's syndrome. Ophthalmic Genet 1996;17:15-9.

162. Catalano RA. Down syndrome. Surv Ophthalmol 1990;34:385-98.

163. Ingersheim J. The relationship of lenticular changes in Mongolism. Trans Am Ophthalmol Soc 1951;49:595-624.

164. Jaeger EA. Ocular findings in Down's syndrome. Trans Am Ophthalmol Soc 1980;158:808-45.

165. Robb RM, Marchevsky A. Pathology of the lens in Down's syndrome. Arch Ophthalmol 1978;96:1039-42.

166. Brown N, Gardner RJM. Lowe syndrome: identification of the carrier state. Birth Defects 1976;12:579-95.

167. Johnson SS, Nevin NC. Ocular manifestations in patients and female relatives of families with the oculocerebrorenal syndrome of Lowe. Birth Defects 1976;12:567-72.

168. Cibis GW, Waeltermann JM, Whitcraft CT, Tripathi RC, Harris DJ. Lenticular opacities in carriers of Lowe's syndrome. Ophthalmology 1986;93:1041-5.

169. Lavin CW, McKeown CA. The oculocerebrorenal syndrome of Lowe. Int Ophthalmol Clin 1993;33:179-91.

170. Bercovitch L, Donaldson DD. The history of congenital sutural cataracts. J Pediatr Ophthalmol Strabismus 1982;19:108-10.

171. Krill AE, Woodbury G, Bowman JE. X-chromosomal linked sutural cataracts. Am J Ophthalmol 1969;68:867-72.

172. Gunn RM. Peculiar coralliform cataract with crystals (?of cholesterine) in the lens. Trans Ophthalmol Soc UK 1895;15:119.

173. Nettleship E. Seven new pedigrees of hereditary cataracts. Trans Ophthalmol Soc UK 1909;29:188-211.

174. Polse KA, Harris MG, Rosen NJ. Familial congenital coralliform cataract. Am J Optom Physiol Optics 1974;51:770-3.

175. Happle R, Küchle H. Sectoral cataract: a possible example of Lyonisation. Lancet 1983;ii:919-20. 
176. Gellis SS, Feingold M. The Stickler syndrome (hereditary arthro-ophthalmopathy). [Picture of the month]. Am J Dis Child 1976;130:65-6.

177. Seery CM, Pruett RC, Lieberfarb RM, Cohen BZ. Distinctive cataract in the Stickler syndrome. Am J Ophthalmol 1990;110:143-9.

178. Spallone A. Stickler's syndrome: a study of 12 families. Br J Ophthalmol 1987;71:504-9.

179. Mackenzie W. A practical treatise on the disease of the eye. London: Longman, Orme, Brown, Green and Longman, 1840.

180. Reese AB. Persistent hyperplastic primary vitreous. Am J Ophthalmol 1955;40:317-31.

$180^{\mathrm{a}}$ Goldberg MF. Persistent fetal vasculature: an integrated interpretation of signs and symptoms associated with persistent hyperplastic primary vitreous (PHPV). LIV Edward Jackson Memorial Lecture. Am J Ophthalmol 1997;124:587-626.

181. Kurz GH, Einaugler RB. Intralenticular hemorrhage following discission of congenital cataract. Am J Ophthalmol 1968;66:1163-5.

182. Madroszkiewicz M. An unusual case of congenital presence of blood in the lens. Ophthalmologica 1974;168:462-4.

183. Unoki K, Nakao K, Ohba N. Haemorrhage in the lens: spontaneous occurrence in congenital cataract. $\mathrm{Br} \mathrm{J}$ Ophthalmol 1986;70:593-5.

184. Haddad R, Font RL, Reeser F. Persistent hyperplastic primary vitreous: a clinicopathologic study. Surv Ophthalmol 1978;23:123-42.

185. Karr DJ, Scott WE. Visual acuity results following treatment for persistent hyperplastic primary vitreous. Arch Ophthalmol 1986;104:662-7.

186. Brown NA, Sparrow JM, Bron AJ. Central compaction in the process of lens growth as indicated by lamellar cataract. Br J Ophthalmol 1988;72:538-44.

187. Gordon RA, Donzis PB. Refractive development of the human eye. Arch Ophthalmol 1985;103:785-9.

188. Doggart JH. Congenital cataract. Trans Ophthalmol Soc UK 1957;77:31-7.

189. Cordes FC. Galactosemia cataract: a review. Am J Ophthalmol 1960;50:1151-8.

190. Reiter C, Lasky MA. Galactose cataracts. Am J Ophthalmol 1952;35:69-75.

191. Bruck E, Rapoport S. Galactosemia in an infant with cataracts: clinical observations and carbohydrate studies. Am J Dis Child 1945;70:267.

192. Greenman L, Rathbun JC. Galactose studies in an infant with idiopathic galactose intolerance. Pediatrics 1948;2:666.

193. Burke JP, O'Keefe M, Bowell R, Naughten ER. Ophthalmic findings in classical galactosemia: a screened population. J Pediatr Ophthalmol Strabismus 1989;26:165-8.

194. Hayasaka S, Shiono T, Konno T, Tateda H. Galactose cataract in Japanese patient. Jpn J Ophthalmol 1982;26:443-6.

195. Wilson WA, Donnell GN. Cataracts in galactosemia. Arch Ophthalmol 1958;60:215-22.

196. Gunn D. Notes on some forms of congenital cataract. Ophthalmic Rev 1898;17:129-43.

197. Hull D. Cataracts associated with metabolic defects. Proc R Soc Med 1969;62:694.

198. Keith CG. The aetiology of congenital and infantile cataracts. Aust J Ophthalmol 1974;12:126-34.

199. Hiles DA, Carter BT. Classification of cataracts in children. In: Hiles DA, editor. Infantile cataract surgery. Boston: Little, Brown, 1977:15-31.

200. Eckstein M, Vijayalakshmi P, Killedar M, Gilbert C. Aetiology of childhood cataract in South India. Br J Ophthalmol 1996;80:628-32.

201. Lambert SR, Drack AV. Infantile cataracts. Surv Ophthalmol 1996;40:427-58.
202. Hiles DA, Biglan AW. Indications for infantile cataract surgery. In: Hiles DA, editor. Infantile cataract surgery. Boston: Little, Brown, 1977:39-49.

203. Kennerdell JS. Preoperative evaluation of the juvenile cataract. In: Hiles DA, editor. Infantile cataract surgery. Boston: Little, Brown, 1977:3-15.

204. Drummond GT, Scott WE, Keech RV. Management of monocular congenital cataracts. Arch Ophthalmol 1989;107:45-51.

205. McCulloch DL, Skarf B. Pattern reversal visual evoked potentials following early treatment of unilateral, congenital cataracts. Arch Ophthalmol 1994;112:510-8.

206. Nucci P, Brancato P. Pattern reversal visual evoked potentials following early treatment of unilateral congenital cataract [letter]. Arch Ophthalmol 1995;113:404-5.

207. Kriss A, Thompson D, Lloyd C, Jeffrey B, Russell-Eggitt I, Taylor DSI. Pattern VEP findings in young children treated for unilateral congenital cataract. In: Cotlier E, Lambert S, Taylor D, editors. Congenital cataracts. Austin, Texas: RG Landes, 1994:79-88.

208. Thompson DA, Moller H, Russell-Eggitt I, Kriss A. Visual acuity in unilateral cataract. Br J Ophthalmol 1996;80:794-8.

209. Lloyd IC, Dowler JGF, Kriss A, Speedwell L, Thompson DA, Russell-Eggitt I, et al. Modulation of amblyopia therapy following early surgery for unilateral congenital cataracts. Br J Ophthalmol 1995;79:802-6.

210. Lloyd C, Dowler J, Kriss A, Russell-Eggitt I, Taylor DSI. Preferential looking and the management of congenital cataract: new occlusion protocols. In: Cotlier E, Lambert S, Taylor D, editors. Congenital cataracts. Austin, Texas: RG Landes, 1994:93-101.

211. Lewis TL, Maurer D, Brent HP. Development of grating acuity in children treated for unilateral or bilateral congenital cataract. Invest Ophthalmol Vis Sci 1995;36:2080-95.

212. Mayer DL, Moore B, Robb RM. Assessment of vision and amblyopia by preferential looking tests after early surgery for unilateral congenital cataracts. J Pediatr Ophthalmol Strabismus 1989;26:61-8.

213. Newton FH. Congenital cataracts: a review of 84 cases. Am J Ophthalmol 1961;52:368.

214. Black RK. The place of optical iridectomy in the treatment of developmental cataract. Trans Ophthalmol Soc UK 86:287-90.

215. Hammami H, Scouras J, Streiff EB. Cataractes congénitales: résultats opératoires et études statistiques sur une période de plus de 25 ans. Ophthalmologica 1972;164:422-39.

216. Guillaumat L. Les cataractes congénitales. Bull Soc Ophtalmol Fr 1970;83:65-91.

217. Sheppard RW, Crawford JS. The treatment of congenital cataracts. Surv Ophthalmol 1973;17:340-7.

218. Weber SW, Crawford JS, Arndt JH, Parker JS. Visual acuity after iridectomy or aspiration for congenital cataract: experimental and clinical studies. Can J Ophthalmol 1978;13:229-36.

219. Kugelberg U. Visual acuity following treatment of bilateral congenital cataracts. Doc Ophthalmol 1992;82:211-5.

220. Guo S, Nelson LB, Calhoun J, Levin A. Simultaneous surgery for congenital cataracts. J Pediatr Ophthalmol Strabismus 1990;27:23-5.

221. Kushner BJ. Discussion (Simultaneous surgery for bilateral congenital cataracts). J Pediatr Ophthalmol Strabismus 1990;27:26-8.

222. Good WV, Hing S, Hoyt CS, Taylor DSI. Postoperative endophthalmitis in children following cataract surgery. J Pediatr Ophthalmol Strabismus 1990;27:283-4.

223. Wheeler DT, Stager DR, Weakley DR. Endophthalmitis following pediatric intraocular surgery for congenital cataracts and congenital glaucoma. J Pediatr Ophthalmol Strabismus 1992;29:139-41. 
224. Zwaan J. Simultaneous surgery for bilateral pediatric cataracts. Ophthalmic Surg Lasers 1996;27:15-20.

225. D'Esposito M, Magli A, Daniele A. Functional recovery in paediatric cataract. Eur J Implant Refract Surg 1990;2:261-4.

226. Scheie HG, Rubinstein RA, Kent RB. Aspiration of congenital or soft cataracts: further experience. Am J Ophthalmol 1967;63:3-8.

227. Parks MM. Intracapsular aspiration. In: Hiles D, editor. Infantile cataract surgery. Boston: Little, Brown, 1977:59-74.

228. Taylor DSI. Choice of surgical technique in the management of congenital cataract. Trans Ophthalmol Soc UK 1981;101:25-38.

229. Parks MM. Management of the posterior capsule in congenital cataracts. J Pediatr Ophthalmol Strabismus $1984 ; 21: 114-6$

230. Caputo AR, Guo S, Wagner RS, Constad WH. A modified extracapsular cataract extraction for pediatric cataracts. Ophthalmic Surg 1991;21:397-403.

231. Eustis HS, Walton RC, Ball SF. Pupillary block glaucoma following pediatric cataract extraction. Ophthalmic Surg 1990;21:413-5.

232. Tartarella MB, Kawakami LT, Scarpi MJ, Hayashi S, Bonomo PP. Aspectos cirúrgicos em cataracta congênita. Arq Bras Oftal 1995;58:24-8.

233. Kaufer G. Congenital cataract: a survey of 81 cases. J Pediatr Ophthalmol 1966;3:46-52.

234. Godde-Jolly D, Ruellan YM, Rozenbaum JP. Cataractes congénitales: 194 cas de phacophagie par voie antérieure. J Fr Ophtalmol 1982;5:761-70.

235. France TD. Management of the posterior capsule in congenital cataracts. J Pediatr Ophthalmol Strabismus 1984;21:116-8.

236. Hiles DA, Atkinson CS. Surgery of bilateral and unilateral cataracts fn children. In: Cotlier E, Lambert S, Taylor D, editors. Congenital cataracts. Austin, Texas: Landes, 1994:127-37.

237. Basti S, Ravishankar U, Gupta S. Results of a prospective evaluation of three methods of management of pediatric cataracts. Ophthalmology 1996;103:713-20.

238. Treister G, Machemer R. Pars plana approach for pupillary membranes. Arch Ophthalmol 1978;96:1914.

239. Peyman GA, Sanders DR, Rose M, Korey M. Vitrophage in management of congenital cataracts. Graefes Arch Ophthalmol 1977;202:305-8.

240. Peyman GA, Raichand M, Goldberg MF. Surgery of congenital and juvenile cataracts: a pars plicata approach with the vitrophage. Br J Ophthalmol 1978;62:780-3.

241. Green BF, Morin JD, Brent HP. Pars plicata lensectomy/ vitrectomy for developmental cataract extraction: surgical results. J Pediatr Ophthalmol Strabismus 1990;27:229-32.

242. Peyman GA, Riachand M, Oesterle C, Goldberg MF. Pars plicata lensectomy and vitrectomy in the management of congenital cataracts. Ophthalmology 1981;88:437-9.

243. Grossman SA, Peyman GA. Long-term visual results after pars plicata lensectomy-vitrectomy for congenital cataracts. Br J Ophthalmol 1988;72:601-6.

244. Dietl RH, Stefani FH. Topographisch-chirurgische Anatomie der kindlichen Pars plana. Ophthalmologica 1986;193:1-9.

245. Morgan KS, Karcioglou ZA. Secondary cataracts in infants after lensectomies. J Pediatr Ophthalmol Strabismus 1987;24:45-8.

246. Lambert SR, Fernandes A, Drews-Botsch C, Tigges M. Pseudophakia retards axial elongation in neonatal monkey eyes. Invest Ophthalmol Vis Sci 1996;37:451-8.

247. Oliver M, Milstein A, Pollack A. Posterior chamber lens implantation in infants and juveniles. Eur J Implant Refract Surg 1990;2:309-14.

248. Christiansen S, Munoz M, Capó H. Retinal hemorrhage following lensectomy and anterior vitrectomy in children. J Pediatr Ophthalmol Strabismus 1993;30:24-7.
249. Mets M, Del Monte M. Hemorrhagic retinopathy following childhood cataract extraction [letter]. Arch Ophthalmol 1986;104:975-9.

250. Gieser SC, Apple DJ, Loftfield K, Richey MA, Rivera RP. Phthisis bulbi after intraocular lens implantation in a child. Can J Ophthalmol 1985;20:184-5.

251. Yamamoto M. Ophthalmic surgery and corneal endothelium. Fol Ophthalmol Jpn 1988;39:1311-8.

252. Goyal JI, Panda A, Angra SK. Corneal endothelial changes following pars plana lensectomy. Ind J Ophthalmol 1991;39:25-7.

253. Hiles DA, Biglan AW, Fetherolf EC. Central corneal endothelial cell counts in children. Am Intraoc Implant Soc J 1979;5:292-300.

254. Olsen $\mathrm{T}$. The endothelial cell density after cataract surgery in young patients. Acta Ophthalmol (Copenh) 1981;59:242-6.

255. Deluise VP, Cobo LM, Chandler D. Persistent corneal edema in the congenital rubella syndrome. Ophthalmology 1983;90:835-9.

256. Yamomoto M. Long-term prognosis of intraocular lens implantation in children. Eur J Implant Refract Surg 1990;2:291-3.

257. Chrousos GA, Parks MM, O'Neil JF. Incidence of chronic glaucoma, retinal detachment and secondary membrane surgery in pediatric patients. Ophthalmology 1984;9:1238-41.

258. Kohnen T, Pena Cuesta R, Koch DD. Secondary cataract formation following pediatric intraocular lens implantation: 6-month results. Germ J Ophthalmol 1996;5:171-5.

259. McDonnell PJ, Stark WJ, Green RW. Posterior capsule opacification: a specular microscopic study. Ophthalmology 1984;91:853-7.

260. Apple DJ, Soloman KD, Tetz MR, Assia EI, Holland EY, Legler UFC, et al. Posterior capsule opacification. Surv Ophthalmol 1992;37:73-116.

261. Liu CSC, Wormstone IM, Duncan G, Marcantonio JM, Webb SF, Davies PD. A study of human lens cell growth in vitro. Invest Ophthalmol Vis Sci 1996;37:906-14.

262. Frezzotti R, Caprossi A, Mastrangelo D, Hadjistilianou T, Tosi P, Cintorino C, et al. Pathogenesis of posterior capsular opacification. II. Histopathological and in vitro culture findings. J Cataract Refract Surg 1990;16:353-60.

263. Wormstone IM, Liu CSC, Rakic J-M, Marcantonio JM, Vrensen GFJM, Duncan G. Human lens epithelial cell proliferation in a protein-free medium. Invest Ophthalmol Vis Sci 1997;38:369-404.

264. Knight-Nanan D, O'Keefe M, Bowell R. Outcome and complications of intraocular lenses in children with cataract. J Cataract Refract Surg 1994;22:730-6.

265. Buckley E, Khombers L, Seaber J, Scalise-Gordy A, Mintzer $R$. Management of the posterior capsule during pediatric intraocular lens implantation. Am J Ophthalmol 1993;115:722-8.

266. Girard LJ. Aspiration-irrigation of congenital and traumatic cataracts. Arch Ophthalmol 1967;77:387-91.

267. Keech RV, Tongue AC, Scott WE. Complications after surgery for congenital and infantile cataracts. Am J Ophthalmol 1989;108:136-41.

268. Gimbel H. Posterior capsulorhexis with optic capture in pediatric cataract and intraocular lens surgery. Ophthalmology 1996;103:1871-5.

269. Atkinson CS, Hiles DA. Treatment of secondary posterior capsular membranes with the Nd:YAG laser in a pediatric population. Am J Ophthalmol 1994;118:496-501.

270. Maltzmann BA, Wagner RS, Caputo AR. Neodymium: YAG laser surgery: the treatment of pediatric cataract disease. Am J Ophthalmol 1986;18:245-6.

271. Ryan SJ, Blanton FM, Von Noorden GK. Surgery of congenital cataract. Am J Ophthalmol 1965;66:583-7. 
272. François J. Late results of congenital cataract surgery. J Pediatr Ophthalmol 1970;7:139-45.

273. Kanski JJ, Elkington AR, Daniel R. Retinal detachment after congenital cataract surgery. Br J Ophthalmol 1974;58:92-5.

274. Toyofuku H, Hirose T, Schepens C. Retinal detachment following congenital cataract surgery. Arch Ophthalmol 1980;98:669-75.

275. Jagger JD, Cooling RJ, Fison LG, Leaver PK, McLeod D. Management of retinal detachment following congenital cataract surgery. Trans Ophthalmol Soc UK 1983;103:103-7.

276. McLeod D. Congenital cataract surgery: a retinal surgeon's viewpoint. Aust NZ J Ophthalmol 1986;14:79-84.

277. Simon JW, Mehta N, Simmons ST, Catalano RA, Lininger LL. Glaucoma after pediatric lensectomy/vitrectomy. Ophthalmology 1991;98:670-4.

278. Robb R, Peterson RA. Outcome of treatment for bilateral congenital cataracts. Trans Am Ophthalmol Soc 1992;90:183-200.

279. Schrader W, Rath M, Witschel H. Spätkomplikationen und funktionelle Ergebnisse mindenstens 5 Jahre nach Parsplana-Lentectomie wegen kongenitaler Katarakt. Ophthalmologe 1994;91:490-7.

280. Biglan AW, Cheng KP, Davis JS, Gerontis CC. Secondary intraocular lens implantation after cataract surgery in children. Am J Ophthalmol 1997;123:224-34.

281. Egbert JE, Kushner BJ. Excessive loss of hyperopia: a presenting sign of juvenile aphakic glaucoma. Arch Ophthalmol 1990;108:1257-9.

282. Chandler PA. Surgery of the lens in infancy and childhood. Arch Ophthalmol 1951;45:125-38.

283. Chandler PA. Surgery of congenital cataracts. The 24th Edward Jackson Memorial Lecture. Am J Ophthalmol 1968;65:663-70.

284. Brady KM, Atkinson CS, Kilty LA, Hiles DA. Cataract surgery and intraocular lens implantation in children. Am J Ophthalmol 1995;120:1-9.

285. Crouch ER, Pressman SH, Crouch ER. Posterior chamber intraocular lenses: long term results in pediatric cataract patients. J Pediatr Ophthalmol Strabismus 1995;32:210-8.

286. Zetterstrom C, Kugelberg U, Scarson C. Cataract surgery in children with capsulorhexis of anterior and posterior capsules and heparin surface-modified intraocular lenses. J Cataract Refract Surg 1994;20:599-601.

287. Vajpayee RB, Talwar D. Pseudophakic malignant glaucoma in a child. Ophthalmic Surg 1991;22:266-7.

288. Cordes FC. Failure in congenital cataract surgery. The 12th Edward Jackson Memorial Lecture. Am J Ophthalmol 1957;43:1-21.

289. Jones IS. The treatment of congenital cataract by needling. Am J Ophthalmol 1961;52:347-55.

290. Phelps CD, Arafat NI. Open angle glaucoma following surgery for congenital cataracts. Arch Ophthalmol 1977;95:1985-7.

291. Munoz M, Parrish RK, Murray TG. Open-angle glaucoma after pars plicata lensectomy and vitrectomy for congenital cataracts. Am J Ophthalmol 1995;119:103-4.

292. Asrani SG, Wilensky JT. Glaucoma after congenital cataract surgery. Ophthalmology 1995;102:863-7.

293. Mills MD, Robb RM. Glaucoma following childhood cataract surgery. J Pediatr Ophthalmol Strabismus 1996;31:355-60.

294. Wallace DK, Plager DA. Corneal diameter in childhood aphakic glaucoma. J Pediatr Ophthalmol Strabismus 1996;33:230-4.

295. Walton DS. Pediatric aphakic glaucoma: a study of 65 patients. Trans Am Ophthalmol Soc 1995;93:403-13.

296. Barnhorst D, Meyers SM, Myers T. Lens-induced glaucoma 65 years after congenital cataract surgery. Am J Ophthalmol 1994;118:807-8.
297. Taylor DSI. Developments in the treatment of cataract: The Treacher Collins Prize Essay 1982. Trans Ophthalmol Soc UK 1982;102:441-53.

298. Hoyt CS, Nickel B. Aphakic cystoid macular edema. Arch Ophthalmol 1982;100:746-9.

299. Poer DV, Helveston EM, Ellis FD. Aphakic cystoid macular edema in children. Arch Ophthalmol 1981;99:249-52.

300. Gilbard SM, Peyman GA, Goldberg MF. Evaluation for cystoid maculopathy after pars plicata lensectomyvitrectomy for congenital cataracts. Ophthalmology 1983;90:1201-6.

301. Morgan KS, Franklin RM. Oral fluorescein angioscopy in aphakic children. J Pediatr Ophthalmol Strabismus 1984;21:33-6.

302. Garcia-Garduño L, Fleitman J. Incidence of aphakic macular edema in congenital cataract. In: Cotlier E, Lambert S, Taylor D, editors. Congenital cataract. Austin, Texas: RG Landes, 1994:139-41.

303. Scheie HG, Schaffer DB, Plotkin SA, Kertesz ED. Congenital rubella cataracts: surgical results and virus recovery from intraocular tissue. Arch Ophthalmol 1967;77:440.

304. Cotlier E, Fox J, Smith M. Rubella virus in the cataractous lens of congenital rubella syndrome. Am J Ophthalmol 1966;62:233-6.

305. Menser MA, Harley JD, Hertzberg R, Dorman DC, Murphy AM. Persistence of virus in lens for three years after prenatal rubella. Lancet 1967;2:387-8.

306. Cotlier E. Congenital varicella cataract. Am J Ophthalmol 1978;86:627-9.

307. Boniuk V, Boniuk M. The incidence of phthisis bulbi as a complication of cataract surgery in the congenital rubella syndrome. Trans Am Acad Ophthalmol Otol 1970;74:360-8.

308. Weiss DI, Ziring PR, Cooper LZ. Surgery of rubella cataract. Am J Ophthalmol 1972;73:326-32.

309. Wolfe SM. The ocular manifestations of congenital rubella: a prospective study of 328 cases. J Pediatr Ophthalmol 1973;10:101-41.

310. Jameson NA, Good WV, Hoyt SC. Inflammation after cataract surgery in children. Ophthalmic Surg 1992;23:99-102.

311. Wiesel TN, Raviola E. Myopia and eye enlargement after neonatal lid fusion in monkeys. Nature 1977;266:66-8.

312. Miles FA, Wallman J. Local ocular compensation for imposed local refractive error. Vision Res 1990;30:339-49.

313. Scahaeffel F, Troilo D, Wallman J, Howland HC. Developing eyes that lack accommodation grow to compensate for imposed defocus. Vis Neurosci 1990;4:177-83.

314. Raviola E, Wiesel TN. Effect of dark-rearing on experimental myopia in monkeys. Invest Ophthalmol Vis Sci $1978 ; 17: 485-8$

315. Wiesel TN, Raviola E. Increase in the axial length of the macaque monkey eye after corneal opacification. Invest Ophthalmol Vis Sci 1979;18:1232-6.

316. Rasooly R, Benezra D. Congenital and traumatic cataract: the effect on ocular axial length. Arch Ophthalmol 1988;106:1066-8.

317. Crewther SG, Nathan J, Kiely PM, Brennan NA, Crewther DP. The effect of defocussing contact lenses on refraction in cynomolgus monkeys. Clin Vis Sci 1988;3:221-8.

318. Rabin J, Van Sluyters RC, Malach R. Emmetropisation: a vision-dependent phenomenon. Invest Ophthalmol Vis Sci 1981;20:561-4.

319. Johnson CA, Post RB, Chalupa LM, Lee TJ. Monocular deprivation in humans: a study of identical twins. Invest Ophthalmol Vis Sci 1982;23:135-8.

320. von Noorden GK, Lewis RA. Ocular axial length in unilateral congenital cataracts and blepharoptosis. Invest Ophthalmol Vis Sci 1987;28:750-2. 
321. Morris JA, Taylor D, Rogers JE, Vaegan, Warland J. Contact lens treatment of aphakic infants and children. J Br Contact Lens Assoc 1979;2:22-30.

322. Schulz E. Visual development and refractive changes in congenital cataract. Eur J Implant Refract Surg 1990;2:253-6.

323. Lorenz B, Wörle J, Friedl N, Hasenfratz G. Ocular growth in infant aphakia. Ophthalmic Paediatr Genet 1993;14:177-88.

324. McClatchey SK, Parks MM. Myopic shift after cataract removal in childhood. J Pediatr Ophthalmol Strabismus 1997;34:88-95.

325. Awner S, Buckley EG, De Varo JM, Seaber JH. Unilateral pseudophakia in children under 4 years. J Pediatr Ophthalmol Strabismus 1996;33:230-6.

326. Huber $C$. Increasing myopia in children with intraocular lenses ( $\mathrm{IOL}$ ): an experiment in form deprivation myopia? Eur J Implant Refract Surg 1993;5:154-8.

327. Kora Y, Shimizu K, Inatomi M, Fukado Y, Ozawa T. Eye growth after cataract extraction and intraocular lens implantation in children. Ophthalmic Surg 1993;24:467-75.

328. BenEzra D. Cataract surgery and intraocular lens implantation in children [letter]. Am J Ophthalmol 1996;121:224-7.

329. Thouvenin D, Lesueur L, Arne JL. Implantation intercapsulaire dans les cataractes de l'enfant. Étude de 87 cas et comparaison à 88 cas sans implantation. J Fr Ophtalmol 1995;18:678-87.

330. Migdal C. Congenital cataracts: management and visual results (Cape Town 1956-1976). J Pediatr Ophthalmol Strabismus 1981;18:13--21.

331. Jain IS, Pillai P, Gangwar DN, Gopal L, Dhir SP. Congenital cataract: management and results. J Pediatr Ophthalmol Strabismus 1983;20:243-6.

332. Ruben M. Role of contact lenses in aphakia in infants and young children. Proc R Soc Med 1969;62:696-9.

333. Davies PD, Tarbuck DTH. Management of cataracts in infancy and childhood. Trans Ophthalmol Soc UK 1977;97:148-52.

334. Parks MM, Hiles DA. Management of infantile cataracts. Am J Ophthalmol 1967;63:10-9.

335. Friendly DS, Oldt NW. Contact lenses for aphakic children. In: Hiles DA, editor. Infantile cataract surgery. Boston: Little, Brown, 1977:205-19.

336. Pratt-Johnson JA, Tillson G. Hard contact lenses in the management of congenital cataracts. J Pediatr Ophthalmol Strabismus 1985;22:94-7.

337. Robb RM, Mayer DL, Moore B. Results of early treatment of unilateral congenital cataracts. J Pediatr Ophthalmol Strabismus 1987;24:178-81.

338. Levin AV, Edmonds SA, Nelson LB, Calhoun JN, Harley RD. Extended wear contact lenses for the treatment of pediatric aphakia. Ophthalmology 1988;95:1107-13.

339. Amaya L, Speedwell L, Taylor DSI. Contact lenses for infant aphakia. Br J Ophthalmol 1990;74:150-4.

340. Moore BD. Pediatric aphakic contact lens wear: rates of successful wear. J Pediatr Ophthalmol Strabismus 1993;30:253-8.

341. Neumann D, Weissman BA, Isenberg SJ, Rosenbaum A, Bateman JB. The effectiveness of daily wear contact lenses for the correction of infantile aphakia. Arch Ophthalmol 1993;111:927-30.

342. Holmstrom G, Speedwell L, Taylor DSI. Contact lenses: still the only solution for infant aphakia. Eur J Implant Refract Surg 1990;2:265-7.

343. Hoyt CS. The optical correction of pediatric aphakia [editorial]. Arch Ophthalmol 1986;104:651-2.

344. Baker JD. Contact lenses. Surv Ophthalmol 1990;34:366-71.

345. Moore BD. Changes in aphakic refraction of children with unilateral congenital cataracts. J Pediatr Ophthalmol Strabismus 1989;26:290-5.
346. Taylor DSI. Risks and difficulties of the treatment of aphakia in infancy. Trans Ophthalmol Soc UK 1982;102:403-6.

347. Epstein RJ, Fernandes A, Gammon JA. The correction of aphakia in infants with hydrogel extended wear contact lenses. Ophthalmology 1988;95:1102-6.

348. Amos CF, Lambert SR, Ward MA. Rigid gas permeable contact lens correction of aphakia following congenital cataract removal during infancy. J Pediatr Ophthalmol Strabismus 1992;29:243-5.

349. BenEzra D, Rose L. Intraocular versus contact lenses for the correction of aphakia in unilateral congenital and developmental cataract. Eur J Implant Refract Surg 1990;2:303-7.

350. Enoch JM, Hamer RD. Image size correction of the unilateral aphakic infant. Ophthalmic Paediatr Genet 1983;2:153-65.

351. Poggio EC, Glynn RJ, Schein OD, Seddon JM, Shannon MJ, Scardino VA, et al. The incidence of ulcerative keratitis among users of daily-wear and extended-wear soft contact lenses. N Engl J Med 1989;321:779-83.

352. Glynn RJ, Schein OD, Seddon JM, Poggio EC, Goodfellow JR, Scardino VA, et al. The incidence of ulcerative keratitis among aphakic contact lens wearers in New England. Arch Ophthalmol 1991;109:104-7.

353. Chan WK, Weissman BA. Comeal pannus associated with contact lens wear. Am J Ophthalmol 1996;121:540-6.

354. Epstein RJ, Fernandes A, Stulting RD, Wright JD, Tigges $\mathrm{MH}$, Gammon JA. Extended-wear contact lens correction of aphakia in infant primates. Ophthalmology 1986;93:1495-501.

355. Morgan KS, Braveman DE, Baker JD. The correction of unilateral aphakia in children treated for orbital rhabdomyosarcoma. J Pediatr Ophthalmol Strabismus 1990;27:70-3.

356. Morgan KS, Werblin TP, Asbell PA, Loupe DN, Friedlander $\mathrm{MH}$. The use of epikeratophakia grafts in pediatric monocular aphakia. J Pediatr Ophthalmol Strabismus 1981;18:23-9.

357. Morgan KS, Stephenson GS, Macdonald MB, Kaufman HC. Epikeratophakia in children. Ophthalmology 1984;91:780-5.

358. Kelly CG, Keates RH, Lembach RG. Epikeratophakia for pediatric aphakia. Arch Ophthalmol 1986;104:680-2.

359. Morgan KS, Arffa RC, Marvelli TL, Verity SM. Five year follow up of epikeratophakia in children. Ophthalmology 1986;93:423-31.

360. Morgan KS, McDonald MB, Hiles DA, Aquavella JV, Durrie DS, Hunkeles JD, et al. The nationwide study of epikeratophakia for aphakia in children. Am J Ophthalmol 1987;103:366-74.

361. Morgan KS, McDonald MB, Hiles DA, Aquavella JV, Durrie DS, Hunkeler JD, et al. The nationwide study of epikeratophakia for aphakia in older children. Ophthalmology 1988;95:526-31.

362. Committee on Ophthalmic Procedure Assessment. Epikeratoplasty. Ophthalmology 1996;103:983-91.

363. Arffa RC, Marvelli TL, Morgan KS. Long term follow up of refractive and keratometric results in pediatric epikeratophakia. Arch Ophthalmol 1986;104:668-70.

364. Binkhorst CD. Iris clip and irido-capsular lens implants (pseudophakoi). Br J Ophthalmol 1967;51:767-71.

365. Binkhorst CD, Gobin MH. Post traumatic artificial lens implants (pseudophakoi) in children. Br J Ophthalmol 1969;53:518-29.

366. Binkhorst CD, Gobin MH. Treatment of congenital and juvenile cataract with intraocular lens implants (pseudophakoi). Br J Ophthalmol 1970;54:759-65.

367. Binkhorst CD, Gobin MH. Congenital cataract and lens implantation. Ophthalmologica 1972;164:392-7.

368. Hiles DA. Intraocular lens implantation in children. Ann Ophthalmol 1977;9:789-97. 
369. Hiles DA. Intraocular lenses in children. In: Hiles D, editor. Infantile cataract surgery. Boston: Little, Brown, 1977:221-42.

370. Vasavada A, Chauhan H. Intraocular lens implantation in infants with congenital cataracts. J Cataract Refract Surg 1994;20:592-8.

371. Taylor DSI. Monocular infantile cataract, intraocular lenses and amblyopia. Br J Ophthalmol 1989;73:857-9.

372. Mehta HK. Biodegradation of nylon loops of intraocular implants in children. Trans Ophthalmol Soc UK 1979;99:183-6.

373. de Courten C, Bucher PJM, BenEzra D. Experience with HEMA lenses in paediatric cataract. Eur J Implant Refract Surg 1990;2:315-8.

374. Markham RHC, Bloom PA, Chandna A, Newcombe EH. Results of intraocular lens implantation in paediatric aphakia. Eye 1992;6:493-8.

375. Wilson ME, Apple DJ, Bluestein EC, Wang X-H. Intraocular lenses for pediatric implantation: biomaterials, designs and sizing. J Cataract Refract Surg 1994;20:584-91.

376. Sinskey RM, Amin P, Stoppel J. Intraocular lens implantation in microphthalmic patients. J Cataract Refract Surg 1992;18:480-4.

377. Ben Ezra D. Intraocular lenses for unilateral paediatric aphakia: early lenses and long-term follow up. Eur J Implant Refract Surg 1990;2:285-9.

378. Drews RC. Clinical use for AC IOLs. Ophthalmology 1995;102:857.

379. Hiles DA. Intraocular lenses. Surv Ophthalmol 1990;34:371-9.

380. Menezo JL, Taboada JF, Ferrer E. Complications of intraocular lenses in children. Trans Ophthalmol Soc UK $1995 ; 104: 546-5 \mathcal{2}$.

381. Lesueur L, Thouvenin D, Arne JL. Résultats visuels et sensoriels du traitement chirurgical des cataractes de l'enfant. À propos de 135 cas. J Fr Ophtalmol 1995;18:667-77.

382. Ellis F. Intraocular lenses in children [editorial]. J Pediatr Ophthalmol Strabismus 1992;29:71-2.

383. Wilson ME, Bluestein EC, Wang XH. Current trends in the use of intraocular lenses in children. J Cataract Refract Surg 1994;20:579-83.

384. Wilson ME. Intraocular lens implantation: has it become the standard of care for children [guest editorial]. Ophthalmology 1996;103:1719-20.

385. Dahan E, Welsh NH, Salmenson BD. Posterior chamber implants in unilateral congenital and developmental cataracts. Eur J Implant Refract Surg 1990;2:295-301.

386. Ben Ezra D, Paez JH. Congenital cataract and intraocular lenses. Am J Ophthalmol 1983;96:311-4.

387. Plager DA, Lipsky SN, Snyder SK, Sprunger DT, Ellis FD, Sondhi N. Capsular management and refractive error in paediatric intraocular lenses. Ophthalmology 1997;104:600-6.

388. Dahan E, Salmenson BD. Pseudophakia in children: precautions, techniques and feasibility. J Cataract Refract Surg 1990;16:75-82.

389. Metge $P$, Cohen $H$, Chemila JF. Intercapsular implantation in children. Eur J Implant Refract Surg 1992;4:319-23.

390. Apple DJ, Mamalis N, Lotfield K, Googe JM, Novak LC, Brady SE, et al. Complications of intraocular lenses: a historical and histopathological review. Surv Ophthalmol 1984;29:1-54.

391. Burke JP, Willshaw HE, Young JDH. Intraocular lens implants for uniocular cataracts in children. $\mathrm{Br} \mathrm{J}$ Ophthalmol 1989;73:860-5.

392. Lesser GR, Osher RH, Whipple D, et al. Treatment of anterior chamber fibrin following cataract surgery with tissue plasminogen activator. J Cataract Refract Surg 1993;19:301.
393. Mittra RA, Dev S, Nasir MA, Toth CA. Recombinant hirudin prevents postoperative fibrin formation after experimental cataract surgery. Ophthalmology 1997;104:558-61.

394. Norris JW, Chirls IA, Santry JG, Norris JW III. Severe fibrinous reaction after cataract and intraocular lens implantation surgery requiring neodymium-YAG laser therapy. J Cataract Refract Surg 1990;16:637-9.

395. Johnson RN, Blankenship G. A prospective, randomised, clinical trial of heparin therapy for postoperative intraocular fibrin. Ophthalmology 1988;95:312-7.

396. Wilson-Holt N, Hing S, Taylor DSI. Bilateral binding uveitis in a child after secondary intraocular lens implantation for unilateral congenital cataract. J Pediatr Ophthalmol Strabismus 1991;28:116-8.

397. Crouch ER Jr, Pressman SH, Crouch ER. Posterior chamber intraocular lenses: Long-term results in pediatric cataract patients. J Pediatr Ophthalmol Strabismus 1995;32:210-8.

398. De Varo JM, Buckley EG, Awner S, Seaber J. Secondary posterior chamber intraocular lens implantation in pediatric patients. Am J Ophthalmol 1997;123:24-30.

399. Lambert SR, Fernandes A, Grossniklaus H, Drews-Botsch C, Eggers H, Boothe RG. Neonatal lensectomy and intraocular lens implantation: effects in rhesus monkeys. Invest Ophthalmol Vis Sci 1995;36:300-10.

400. Lambert SR, Fernandes A, Grossniklaus HE. Haptic breakage following neonatal IOL implantation in a nonhuman primate model. J Pediatr Ophthalmol Strabismus 1995;32:219-24.

401. Fernandes A, Lambert SR, Grossniklaus HE. Glaucoma induced by neonatal implantation in a monkey model. Invest Ophthalmol Vis Sci 1995;36(Suppl):331.

402. Kora Y, Inatomi M, Fukado Y, Marumori M, Yaguchi S. Long-term study of children with implanted intraocular lenses. J Cataract Refract Surg 1992;18:485-8.

403. Hiles DA. Intraocular lens implantation in children with monocular cataracts. Ophthalmology 1984;91:1231-8.

404. Sinskey RM, Stoppel JO, Amin P. Long-term results of intraocular lens implantation in pediatric patients. J Cataract Refract Surg 1993;19:405-8.

405. Dahan E, Salmenson BD, Levin J. Ciliary sulcus reconstruction for posterior implantation in the absence of an intact posterior capsule. Ophthalmic Surg 1989;20:776-80.

406. Scott IU, Flynn HW, Feuer W. Endophthalmitis after secondary intraocular lens implantation. Ophthalmology 1995;102:1925-31.

407. Owens WC. Results of surgical treatment of congenital cataract. Arch Ophthalmol 1948;39:339-50.

408. François J. Treatment of congenital cataracts. Ann Ophthalmol 1970;2:131-9.

409. Hervouet F, Charleux J. Physionomies de la cataracte congénitale en 1979. J Fr Ophtalmol 1977;2:727-34.

410. Rodgers GL, Tishler CL, Tsou BH, Hertle RW, Fellows RR. Visual acuities in infants with congenital cataracts operated on prior to 6 months of age. Arch Ophthalmol 1981;99:999-1003.

411. Lambert SR, Amaya L, Taylor DSI. Detection and treatment of infantile cataracts. Int Ophthalmol Clin 1989;29:51-6.

412. Lorenz B, Wörle J. Visual results in congenital cataract with the use of contact lenses. Graefes Arch Clin Exp Ophthalmol 1991;229:123-32.

413. Abrahamson IA, Abrahamson IA Jr. Modern concepts in the management of congenital cataracts. J Pediatr Ophthalmol 1967;4:35-46.

414. Enoch JM, Rabinowicz IM. Early surgery and visual correction of an infant born with unilateral eye lens opacity. Doc Ophthalmol 1976;41:371-82.

415. Jacobson SG, Mohindra I, Held R. Development of visual acuity in infants with congenital cataracts. $\mathrm{Br} \mathrm{J}$ Ophthalmol 1981;65:727-35. 
416. Von Noorden GK. Factors involved in the production of amblyopia. Br J Ophthalmol 1974;58:158-64.

417. Frey T, Friendly D, Wyatt D. Re-evaluation of monocular cataracts in children. Am J Ophthalmol 1973;76:381-8.

418. Lewis T, Maurer D, Brent H. Effects on perceptual development of visual deprivation during infancy. $\mathrm{Br} \mathrm{J}$ Ophthalmol 1986;70:214-20.

419. Birch EE, Stager DR, Wright WW. Grating acuity development after early surgery for congenital unilateral cataract. Arch Ophthalmol 1986;104:1783-7.

420. Birch EE, Stager DR. Prevalence of good visual acuity following surgery for congenital unilateral cataract. Arch Ophthalmol 1988;106:40-3.

421. Catalano RA, Simon JW, Jenkins PL, Kandel GL. Preferential looking as a guide for amblyopia therapy in monocular infantile cataracts. J Pediatr Ophthalmol Strabismus 1987;24:56-63.

422. Vila-Coro A, Mazow ML. Initiation of amblyopia treatment in monocular congenital cataracts [letter]. Arch Ophthalmol 1989;107:1113.

423. Birch EE, Swanson WH, Stager DR. Outcome after very early treatment of dense congenital unilateral cataract. Invest Ophthalmol Vis Sci 1993;34:3687-98.

424. Moran J, Gordon B. Long term visual deprivation in a human. Vision Res 1982;22:27-36.

425. Cheng KP, Hiles DA, Biglan AW, Pettapiece MC. Visual results after early surgical treatment of unilateral congenital cataracts. Ophthalmology 1991;98:903-10.

426. Goldstein JH, Schneekloth BB. Unilateral congenital cataract and binocular vision [letter]. Ophthalmic Surg 1993;24:560-1.

427. Pratt-Johnson JA, Tillson G. Unilateral congenital cataract: binocular status after treatment. J Pediatr Ophthalmol Strabismus 1989;26:72-5.
428. Tytla ME, Lewis TL, Maurer D, Brent HP. Stereopsis after congenital cataract. Invest Ophthalmol Vis Sci 1993;34:1767-73.

429. Wright KW, Matsumoto E, Edelman PM. Binocular fusion and stereopsis associated with early surgery for monocular congenital cataracts. Arch Ophthalmol 1992;110:1607-9.

430. Yagasaki T, Sato M, Nomura H, Hirai T, Awaya S. A case with stereopsis following early surgery for unilateral congenital cataract. Nippon Ganka Gakkai Zasshi 1994;98:111-6.

431. Gregg F, Parks M. Stereopsis after congenital monocular cataract extraction. Am J Ophthalmol 1992;114:314-7.

432. France TD, Frank JW. The association of strabismus and aphakia in children. J Pediatr Ophthalmol Strabismus 1984;21:223-6.

433. Lewis TL, Maurer D, Tytla ME, Bowering ER, Brent HP. Vision in the 'good' eye of children treated for unilateral congenital cataract. Ophthalmology 1992;9:1013-7.

434. Shawkat FS, Harris CM, Taylor DSI, Thompson DA, Russell-Eggitt I, Kriss A. The optokinetic response differences between congenital profound and non-profound unilateral visual deprivation. Ophthalmology 1995;102:1615-22.

435. Spielmann A. The fate of the 'sound' eye in unilateral congenital cataract. Eur J Implant Refract Surg 1990;2:245-8.

436. Smith KH, Baker DB, Keech RV, Adams LW, Rosa RH, Austin CJ, et al. Monocular congenital cataracts: psychological effects of treatment. J Pediatr Ophthalmol Strabismus 1991;28:245-9.

437. Tommila V, Tarkkanen A. Incidence of loss of vision in the healthy eye in amblyopia. Br J Ophthalmol 1981;65:575-7.

438. Summers CG, Letson R. Is the phakic eye normal in monocular pediatric aphakia? J Pediatr Ophthalmol Strabismus 1992;29:324-7. 